\title{
Performance of northern red oak (Quercus rubra) underplantings under five management regimes and across existing environmental gradients
}

\author{
Adam E. Regula \\ West Virginia University
}

Follow this and additional works at: https://researchrepository.wvu.edu/etd

\author{
Recommended Citation \\ Regula, Adam E., "Performance of northern red oak (Quercus rubra) underplantings under five \\ management regimes and across existing environmental gradients" (2013). Graduate Theses, \\ Dissertations, and Problem Reports. 339. \\ https://researchrepository.wvu.edu/etd/339
}

This Thesis is protected by copyright and/or related rights. It has been brought to you by the The Research Repository @ WVU with permission from the rights-holder(s). You are free to use this Thesis in any way that is permitted by the copyright and related rights legislation that applies to your use. For other uses you must obtain permission from the rights-holder(s) directly, unless additional rights are indicated by a Creative Commons license in the record and/ or on the work itself. This Thesis has been accepted for inclusion in WVU Graduate Theses, Dissertations, and Problem Reports collection by an authorized administrator of The Research Repository @ WVU. For more information, please contact researchrepository@mail.wvu.edu. 
Performance of northern red oak (Quercus rubra) underplantings under five management regimes and across existing environmental gradients

\author{
Adam E. Regula
}

\author{
Thesis submitted to the Davis College of \\ Agriculture, Natural Resources, and Design at West \\ Virginia University in partial fulfillment of the \\ requirements for the degree of \\ Master of Science in Forestry \\ David McGill, Ph.D., Chair \\ Cynthia Huebner, Ph.D. \\ James Rentch, Ph.D. \\ Department of Forestry and Natural Resources
}

Morgantown, West Virginia 2013

Keywords: oak regeneration; underplanting; Appalachian Plateau; Ridge and Valley; oak silviculture 


\begin{abstract}
Performance of northern red oak (Quercus rubra) underplantings under five management regimes and across existing environmental gradients
\end{abstract}

Adam E. Regula

Oaks (Quercus sp.) are dominant throughout much of the eastern broadleaf forests of the United States and are of great ecological, economical, and cultural value. Despite their prevalence in the overstory, many sites are lacking in the advanced reproduction necessary for its regeneration in future stands. This dilemma has merited much research, but widely applicable and consistently successful methods for regenerating oak remain elusive. This study examines the response of northern red oak ( $Q$. rubra) underplantings to forest management regimes across the environmental gradients of physiographic province, aspect, and fencing levels. Management regimes included 1) control sites, 2) a single prescribed burn, 3) repeat prescribed burns 5) diameter-limit cuts and 4) the seedcut of a shelterwood harvest. Physiographic provinces included the Ridge and Valley and Appalachian Plateau. The direct relationships between seedling performance and light as well as light and stand structure are also addressed. Seedling growth and survival are found to be driven by a combination of factors. The interaction of physiographic province and management regime exerted a significant influence on seedling survival. While high survival rates were present on sites receiving diameter-limit cuts and shelterwood cuts regardless of province, underplantings experienced a more dramatic drop in survival on single burn and control sited in the Appalachian Plateau than Ridge and Valley. Sapling density appears as stronger limiting factor of light levels on the more mesic Appalachian Plateau sites, and low survival on these sites reflected this. In contrast, the less dense sapling layer and generally higher light levels of the Ridge and Valley enabled underplanted seedlings to better persist here in the absence of overstory removal. The interaction of fencing and physiographic province was significant as well. Deer, were more problematic in this province, and the potential for herbivory to interfere with seedling response to increased resources was evident. Ultimately, the relatively brief duration of the study limits conclusions on the future of these underplantings, but results reinforce the importance of regional differences in forest composition and structure in determining the effectiveness of prescriptions. An awareness of this is particularly important when considering underplanting. 


\section{ACKNOWLEDGEMENTS}

This document would not have been possible without the assistance and insight of my advisor, Dr. Dave McGill, as well as the other members of my committee, Dr. Cynthia Huebner and Dr. Jim Rentch. I greatly appreciate their efforts to help and work with me through this project. 


\section{CONTENTS}

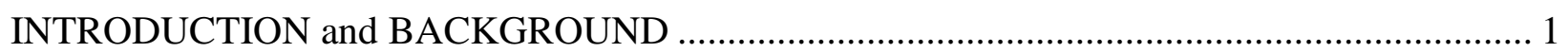

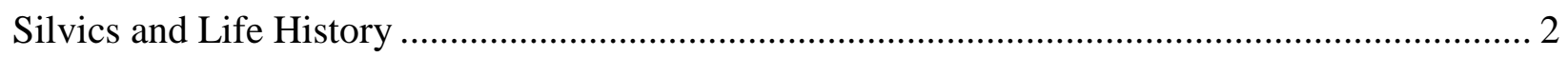

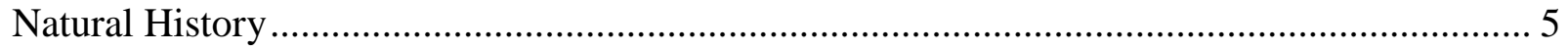

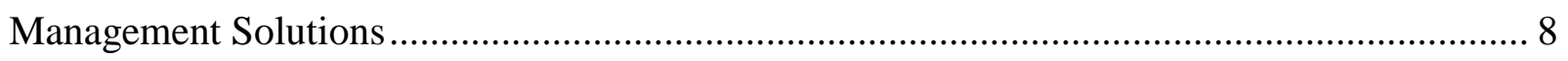

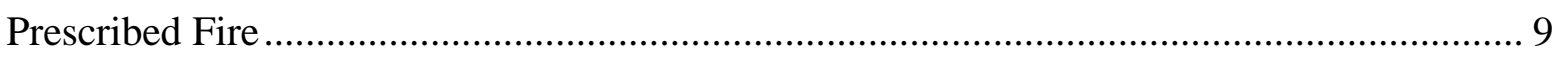

Single Fire

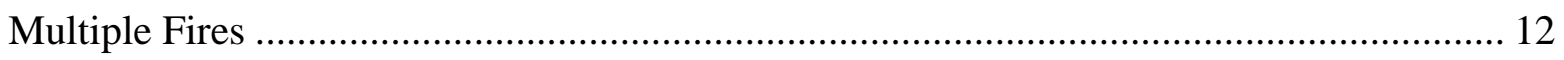

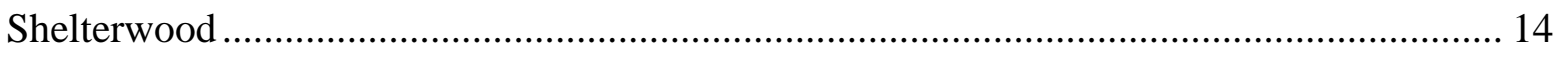

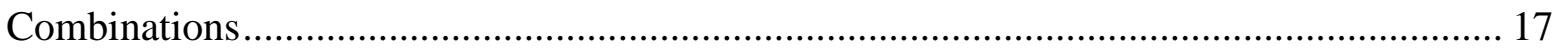

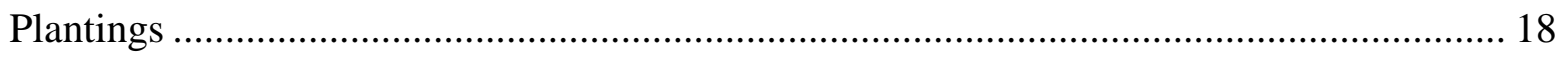

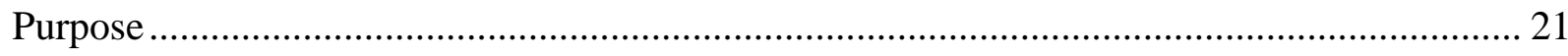

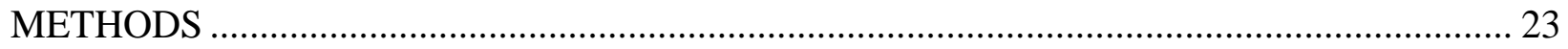

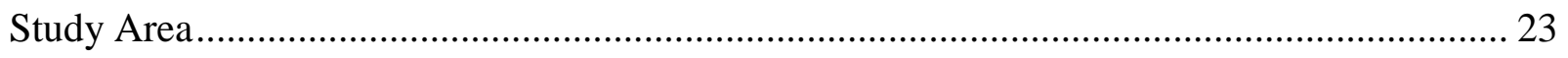

Physiography, Soil and Climate ……………………................................................. 24

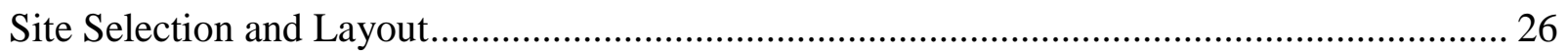

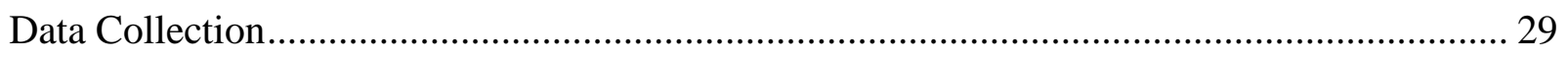

Initial Conditions of Management Regimes................................................................... 30

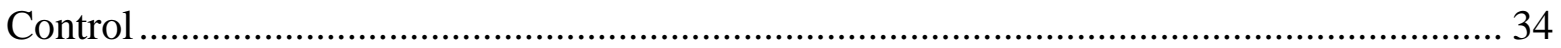

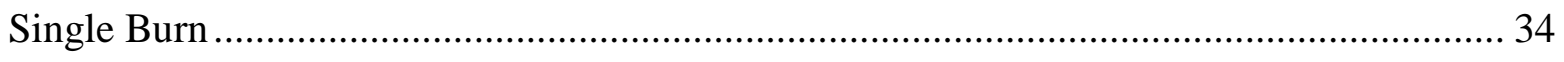

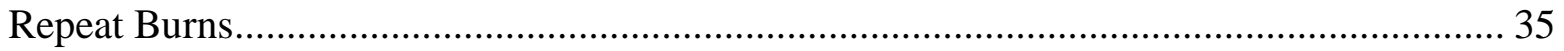

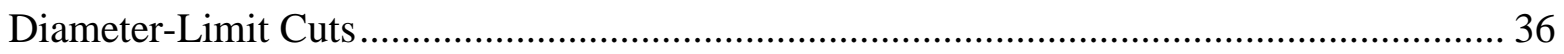

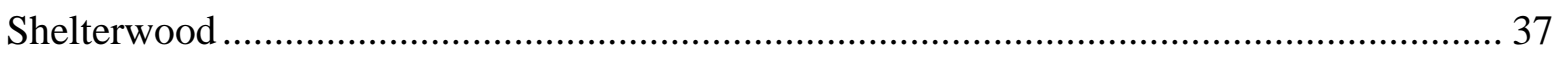

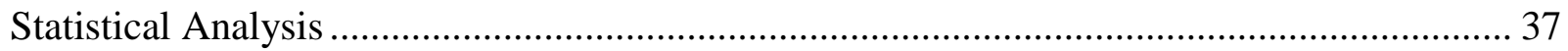

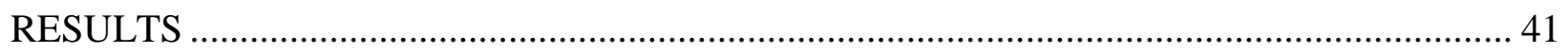

Fixed Effects and Seedling Vigor .................................................................................. 41

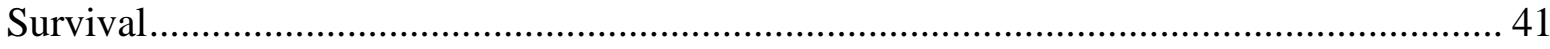

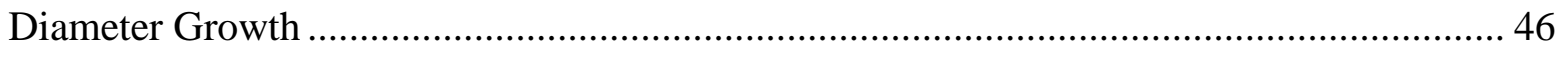

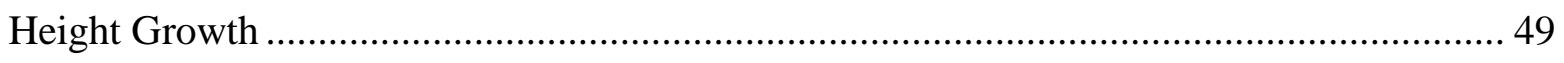

Light, Performance, and Forest Structure …………….......................................................... 51 


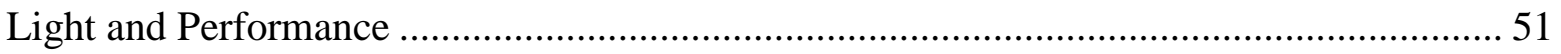

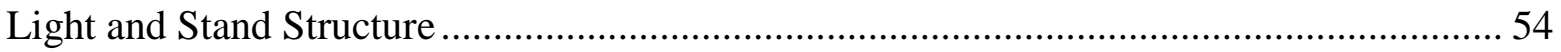

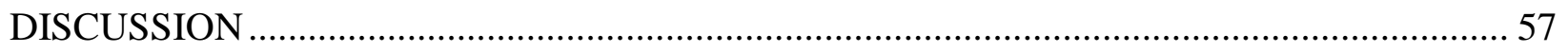

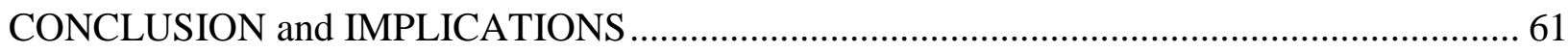

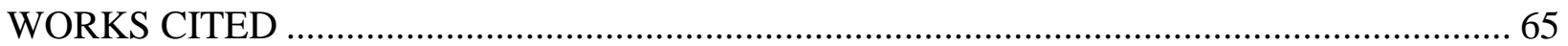

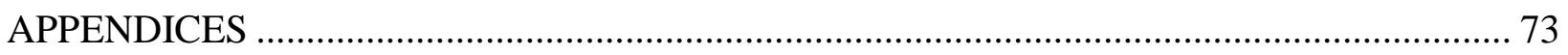




\section{INTRODUCTION and BACKGROUND}

Oaks (Quercus spp.) are important species group throughout the forests of the United States. In the Eastern U.S., the oak-hickory, oak-pine, and oak-gum-cypress cover types accounted for 187 million acres, or 52\%, of timberland in 1997 (USDA Forest Service 2000, Johnson et al. 2002). Covering 124 million acres, the oak-hickory group is the largest forest type in the nation and dominant in much of the central hardwoods region, including the central Appalachians (Johnson et al. 2002, Hicks, 1998). Associated with this prevalence and geographic extent is its ecological and economic importance, as the acorns serve as a food source for wildlife and the wood is used in a variety of products (Johnson et al. 2002, McShea and Healy 2002). However, despite its widespread dominance in eastern deciduous forest ecosystems, the future status of oak is in question. On many sites, the size and quantity of advanced reproduction necessary for successful regeneration and the perpetuation of oaks as a major component of the future stand is lacking (Woodall et al. 2008; Widmann et al. 2012). This is particularly true on higher quality sites where competition is most intense. Unfortunately, these are also the sites most capable of producing fast growing, high quality individuals of the most desirable species such as northern red oak (Quercus rubra) (Dey et al. 2012, Hutchinson et al. 2005, Johnson et al 2002, Larsen and Johnson 1998, Loftis 2004, Schlesinger et al. 1993, Spetich et al. 2002). Given its importance, this has been cause for concern and has prompted abundant research to better understand the origin of oak dominance, drivers behind the inadequacy of regeneration, and prescriptions which address it. However, widely applicable and consistently replicable and successful solutions have proven elusive (Dey et al. 2009, Dey et al. 2007, Dey et al. 2010, Johnson et al. 2002, Loftis 2004). This is partly attributable to the larger geographic extent of oaks' importance (Dey et al. 2009). Sites encompass a diverse range of 
biotic communities and abiotic characteristics, from xeric oak-pine ridgetops to mesic bottomland hardwoods. Direct comparison and implementation of findings across such a range is a challenge (Dey et al. 2010, Johnson et al. 2002). This research hopes to shed light on this dilemma through the underplanting of northern red oak seedlings within the Appalachian Plateau and Ridge and Valley physiographic provinces of central Appalachia. In addition, the effects of management regime, topography, exclusion of deer, and the interactions of these effects are examined.

\section{Silvics and Life History}

The prominence of oak in the overstory of much of today's eastern forests is the product of centuries of natural and anthropogenic forces acting upon the silvical characteristics of oaks. In regards to shade tolerance, oaks range from intermediate to intolerant. Northern red oak specifically is classified as intermediate in tolerance (Baker 1949, Humbert et al. 2007). Growth studies examining the light requirements and thresholds of northern red oak have produced somewhat varying results but generally identify a light compensation point in the range of 2-5\% full sunlight. Increases in photosynthesis plateau between $20 \%$ and $30 \%$ full sunlight (Gottschalk 1994; Johnson et al. 2002; Rebbeck et al. 2011, Rebbeck et al. 2012). Looking at seedling two year performance under $6 \%, 18 \%$, and $25 \%$ full sunlight, Rebbeck et al. (2011) found 25\% greater height and basal diameter growth between $6 \%$ and $25 \%$ full light.. This is consistent with Gottschalk's (1994) findings that increasing full sunlight greater than $20 \%$ may maximize growth, but increases in growth were marginal at levels beyond 30\%. A study by Kaelke (2001) produced more conservative results, showing northern red oak growth response to increased light levels to be comparable to sugar maple (Acer saccharum) which is generally moderate and begins to plateau at $15 \%$ full sunlight. In light of this, the authors suggest that 
increases in photosynthesis and growth associated with light levels greater than $20 \%$ full sunlight were outweighed by the potential benefits to competing species. Despite some differences in specific findings, the general consensus is that northern red oak increases in growth and photosynthesis rate with $20 \%$ full sunlight, and experiences little benefit from light levels beyond 30\% (Gottschalk 1994; Johnson et al. 2002; Rebbeck et al. 2011, Rebbeck et al. 2012).

Oaks display episodic or recurrent shoot growth with total growth for a given year determined by the number of flushes (Crow 1988, Crow et al. 1992, Hanson et al. 1986, Reich et al. 1980). This, in turn, is contingent on suitable environmental conditions and carbohydrate reserves within the root system. One to three flushes per growing season are the norm under natural conditions (Crow 1988, Crow et al. 1992). During periods of rest, carbon allocation is directed to the taproot. This is particularly true during the early stages of growth and development. As a result, oaks are generally understood to exhibit slow early growth, with a greater root to shoot ratio relative to many species (Crow 1988, Crow 1992, Dey and Parker 1997a, Johnson et al. 2002, Reich et al., 1980).

Investing energy in root mass is part of a generally conservative ecological strategy which results in slower initial shoot growth, but also relatively high tolerance of droughty, poorer quality sites (Fedekulegn et al. 2003, Johnson et al. 2002, Spetich et al. 2002). Under such conditions competing vegetation is also diminished and achieving successful natural regeneration with minimally intensive management less problematic (Dey et al. 2012, Hutchinson et al. 2005, Johnson et al 2002, Loftis 2004, Spetich et al. 2002). However, these sites are more likely to produce less desirable species such as chestnut oak (Quercus prinus) and scarlet oak (Quercus coccinea). Furthermore, individuals on these sites show slower growth rates and are ultimately lower quality timber. On more mesic, higher quality sites capable of producing faster growing, 
higher quality northern red oak, the species loses a competitive advantage over competing species such as yellow-poplar (Dey et al. 2010, Johnson et al. 2002, Larsen and Johnson 1998, Nowacki and Abrams 2008, Schuler and Robison 2010).

In addition to higher tolerance of drier sites, a high root to shoot ratio enables oaks to draw on below ground reserves when responding to disturbance and top kill through sprouting. While sprouting is a shared attribute among most hardwood species, oak's preferential allocation of energy to a taproot allows individuals to more readily sprout multiple times in response to repeated disturbances (Crow 1988, Dey et al. 2010, Johnson et al. 2002, Reich et al. 1980). Studies of seedling sprouts have shown that the majority seedlings have experienced periodic dieback and resprouting, evidenced by root systems as much as 30-40 years old with significantly younger shoots (Merz and Boyce 1956, Tryon and Powell 1984). In an assessment of dominant and co-dominant trees Heggenstaller et al. (2012) found that most root systems were 2.3-4.6 years older than the above ground stem and growth rates suggested the majority were products of advanced regeneration, which sprouted following the previous harvest. These seedling sprouts sprout more quickly, have superior xylem conductivity, and are more tolerant of drought than new seedlings (Hodges and Gardiner 1992). This supports the axiom that the presence of advanced reproduction prior to harvest is essential if a substantial component of oak is to be present in the next cohort (Dey et al. 2010, Loftis 2004, Sander 1971, Sander et al. 1976, Steiner et al. 2008). It also highlights the importance of a well-developed root system to fuel sprouts and rapid growth in response to resources (Carvell and Tryon 1961, Johnson et al. 2002, Larsen and Johnson 1998, Sander 1971, Steiner et al. 2008). Advanced reproduction, in combination with historic disturbance regimes, let to the oak dominated forest prevalent today. 


\section{Natural History}

In the past, frequent low intensity fires, first ignited by Native Americans and later by Euro-American settlers, inhibited competing species in the mid and understories and created a pattern of growth and above ground die back. This pattern promoted the establishment of advanced reproduction with substantial root systems while suppressing fire intolerant competition (Abrams 2003, Brose et al. 2001, Guyette et al. 2006, Hart and Buchanan 2012, Hutchinson et al. 2008, Pyne, 1997, Pyne, 2001). With the advent of wide scale industrial logging beginning in the late $19^{\text {th }}$ century, much of eastern hardwood forests were clear cut. These operations left large amounts of slash, fueling high intensity fires. These landscape level, stand replacing, disturbances favored oaks, as well as other eagerly sprouting species with similar regeneration strategies such as the hickories (Carya spp.) (Abrams 2003, Brose et al. 2001, Guyette et al. 2006, Hart and Buchanan 2012, Hutchinson et al. 2008, Nowacki and Abrams 2008).

In response to widespread conflagrations, an era of fire suppression began in the late 1920s, eliminating this disturbance from much of the eastern hardwood forests (Brose et al. 2001, Hutchinson et al. 2008, Nowacki and Abrams 2008, Pyne, 1997, Pyne, 2001). The impacts of this were twofold. First, fire suppression enabled established oaks and advanced reproduction to freely mature to their current status of dominance. The second impact of this policy effectively removed the low intensity, high frequency fire disturbance regime which promoted oak advanced reproduction. This altered fire disturbance regime has resulted in a regional shift in species composition where shade tolerant species such as the shade tolerant maples (Acer spp.) and black gum (Nyssa sylvatica) persist and become well established following gap scale or larger disturbances (Abrams 1998; Kern et al. 20112 Nowacki and 
Abrams 2008; Nyland 2007). As there is often an aesthetic aversion to even-aged methods such as clearcutting, single-tree selection systems, diameter-limit cutting, and light harvests are prevalent in much of the region. Diameter-limit cutting is the removal of all merchantable trees above a designated minimum diameter and may or may not include the removal of cull trees (SAF 2008). It is often primarily guided by short term economic considerations as opposed to future composition and regeneration (Nyland 2005). As a result, the environmental conditions created by diameter-limit cuts can be highly variable. In some cases, diameter-limit cutting has been shown to lead to what Abrams and Nowacki (1992) referred to as post-logging accelerated succession (Oswalt et al. 2006). These management regimes perpetuate the transition to more shade tolerant species composition in that they can fail to create openings of sufficient size to promote the development of shade intolerant species and release advance reproduction of shade tolerant species accumulated in the understory (Dey et al. 2010, Holzmueller et al. 2011, Johnson et al. 2002, Nyland 2005, Nyland 2007). In instances where even-ages management is applied and complete overstory removal occurs, the lack of sufficient and sizeable oak advance reproduction will result in stands dominated by fast growing shade intolerant species such as yellow-poplar (Liriodendron tulipifera) as well as preexisting shade tolerant species.

Compounding the effects of a changing disturbance regime on oak regeneration has been a substantial increase in white-tailed deer (Odocoileus virginianus) population density throughout the eastern United States. Rebounding from near extirpation in much of its eastern range during European settlement, populations now exceed pre-Euro American estimates of 3.1$7.7 \mathrm{deer} / \mathrm{km}^{2}$. In some areas, deer densities have been estimated to be as high as $>60 \mathrm{deer} / \mathrm{km}^{2}$ in mixed agricultural and forested land and 7.7-14.8 deer $/ \mathrm{km}^{2}$ in larger expanses of relatively contiguous forest (Horsley et al. 2003, Knox 1997, McCabe and McCabe 1997). It is difficult to 
quantify the contribution of increased deer densities per se on regeneration problems; deer populations are dynamic in temporal and spatial scales, hence browsing pressure on vegetation must be considered at both site and landscape scales (Horsley et al. 2003). However, it is accepted that herbivory by deer can place additional stress on seedlings already existing under less than ideal conditions. This leads to a general decline in understory vegetation, drives composition toward decreased diversity and dominance by less preferred species and in extreme cases may even result in regeneration failure following harvest. Numerous exclosure studies throughout the region have shown this to be the case when examining the effects of zero deer density within fenced areas in comparison with the "ambient" densities present on the landscape (Cote et al. 2004, Horsley 2003, Marquis and Giesez 1978; Russell et al. 2001, Shafer et al. 1961, Tilghman 1989). Studying a controlled gradient of deer densities within forest compartments, Horsley et al. (2003) found $8 \mathrm{deer} / \mathrm{km}^{2}$ to be a threshold for negative impacts to vegetation, with increasing densities resulting in lower overall stem density and herbaceous cover as well as an increase in importance of non-preferred species such a ferns and black cherry (Prunus serotina). Studying herbivory in southern bottomlands, Castleberry et al. (1999) found red oak to be a highly utilized species by white-tailed deer, and was browsed disproportionately to its abundance. Examining gap effects and shrub competition on advanced reproduction in northern hardwoods, Kern et al. (2012) found that deer browse restricted seedlings from taking full advantage of resources freed by various sized canopy gaps created by silviculural treatments.

Despite research showing negative impacts of high deer impact, deer densities vary across the landscape and as a result, the negative effects of browse are localized and at times absent (Adams and Rieske 2001, Apsley and McCarthy). Apsley and McCarthy (2004) found no real difference between fenced and unfenced plots in a southern Ohio study examining browse in 
conjunction with prescribed burning and thinning. Though the ecological effects of deer herbivory are difficult to tease apart from other ongoing changes on the landscape, there is a general consensus that high densities have the potential to negate silvicultural prescriptions and present a legitimate barrier to regeneration efforts.

Awareness of this lack of advanced reproduction in forests where oaks constitute a large portion of the overstory and concern over the consequences for future stands has developed over the last 50 years (Abrams 1998, Brose et al. 2001, Dey et al. 2010, Iverson et al. 2008, Johnson et al. 2002, loftis 2004, Nowacki and Abrams, 2008, Rentch et al. 2002, Smith 2006). Nowacki and Abrams (2008) termed the recent change in forest disturbance regimes and accompanying shift in composition and structure a process of "mesophication," arguing that a fundamental change in the ecology of fire driven intermediate succession forests has occurred. Furthermore, the authors suggest this transition has occurred to such an extent that it cannot be easily reversed. This shift is apparent at the regional and national scale. Smith (2006) provides evidence of significant change in today's forests in the form of USFS Forest Inventory and Analysis data showing oaks maintaining a relatively stable proportion of growing stock in the eastern United States, while red maple (Acer rubrum) and yellow-poplar have increased 60\% and 35\% respectively. In Ohio, between 1968 and 1991, the relative importance of oaks declined by 22\% compared to a 38\% increase in total volume of maples (Acer spp.) and yellow-poplar (Iverson et al., 2008). Similarly, in Pennsylvania, there was a $22 \%$ increase in red maple dominated forest types between 1989 and 2000 (Iverson et al., 2008).

\section{Management Solutions}

Not surprisingly, the status of current oak regeneration has spurred an abundance of research on potential solutions. This research has largely produced prescriptions which facilitate 
the establishment of advanced reproduction of sufficient size and quantity to provide a high probability of its ascendance to a dominant and co-dominant position. What qualifies as sufficient size and abundance is contingent on management objectives, intensity of competition, and likelihood of stump sprouts following harvest. Sander (1971) found that advanced reproduction stems with less than $1.27 \mathrm{~cm}$ basal diameter were not likely to produce post-harvest sprouts which remained competitive three years following a clearcut. In a separate study, the author found that only stems greater than 4.5 feet in height had greater than $50 \%$ chance of becoming co-dominant; based on this finding it was suggested that 433 stems per acre of this size were necessary at the time of overstory removal to achieve a future stand stocked with $30 \%$ oak (Sander et al. 1976). Steiner et al. (2008) provided a more flexible approach to assessing reproduction by aggregating seedling height to determine a mean stocking value. This aggregate value, along with stump sprout stocking, can serve as an estimate of future percent oak stocking. Regardless of the specific method used to assess oak advanced reproduction, silvicultural prescriptions are primarily concerned with maintaining the appropriate levels of light and sufficient control of competing vegetation.

\section{Prescribed Fire}

As fire is frequently credited with the historical and present dominance of oak, it is natural that the reintroduction of fire, in the form of prescribed burning, be considered a potential solution. Fire and its effect on the landscape are dynamic and highly variable. Season of burn, species composition, weather conditions, aspect, topography, burn frequency, burn intensity, fuel loading, and other factors have the potential to influence fire behavior and a forest community's response. As such, it is complex subject of study and one which has produced a range of mixed results. Studies exploring the effects of prescribed fire belong to one of two classes, those 
examining a single prescribed burn and those examining multiple prescribed fires over several years (Brose et al. 2006). In both cases, the differing spatial and temporal variation between studies have produced mixed results and make any conclusive argument regarding degree of benefits to oak regeneration challenging. However, the body of research does show that prescribed fire is not a panacea, a tool that will rapidly and easily return forests to a previous, desired condition. Instead, the benefits appear to accrue with a long term commitment to burning and its flexible application as one among several management approaches. It should be noted that the discussion of prescribed fire immediately below only addresses its application in the absence of additional prescriptions such as herbicide treatments or thinnings. Its use in combination with regeneration systems and other treatments is considered later.

\section{Single Fire}

The effects of single, low-intensity burns tend to be fleeting and generally fail in altering conditions sufficiently to foster the development of oak advanced reproduction. While the objective of burning for oak regeneration is to favor fire tolerant and vigorously sprouting oak

over competition, it has shown to have the opposite effect in some instances. Nyland et al. (1982) found a single prescribed fire in a mature New York forest to have promoted a dense herbaceous understory with the potential to interfere with oak regeneration. A single fire, low intensity event has also been found to prompt sprouting of competing hardwoods, specifically red maple, effectively increasing their importance relative to that of oak species (Brose 2006, Royse 2009).

In many instances the effects of a single fire are minor, do not extend beyond an initial clearing of herbaceous vegetation and do little, if anything, to alter forest structure or composition in the long term. McGee et al. (1995) found this to be the case when comparing the impact of zero, one, and two fires over the course of four years. Eight and twelve years post- 
burn, the authors reported no increase in either stem density or importance value of northern red oak when compared to pre-burn conditions.

However, some studies have found a single prescribed fire to stimulate oak regeneration. In an eastern Tennessee study, Jackson and Buckley (2004) reported an increase in the density of oak seedling and seedling sprouts $(<10 \mathrm{~cm}$ height $)$ and decrease in red maple seedling density one year following a single fire when compared to control sites. While this gives some support to the potential for a single fire to stimulate oak regeneration, these short term results demand caution in interpretation, especially as longer term findings elsewhere show effects to fade with time. Barnes and VanLear (1998) also found that an increase in oak and hickory and decrease in red maple densities accompanied a single low intensity spring burn. Kruger and Reich (1997) conducted prescribed burns on fenced gap sized openings and found northern red oak seedling density increased by $50 \%$ in comparison with a $90 \%$ decrease in sugar maple densities.

Elliot et al.'s (1999) assessment of vegetation following a single prescribed fire in the southern Appalachians across a mesic bottom to dry ridge top gradient demonstrates the difficulty in drawing generally applicable conclusions from burn studies. Results showed the higher intensity fires on the drier sites tend to cause canopy mortality and increase infiltration of light to the forest floor, subsequently benefiting oak seedlings. In contrast, mid-slope fires had significant mid-story and understory effects but showed little promise in benefitting oak regeneration in the long term, while the bottomland fire had no lasting effect on community composition, herbaceous or otherwise. Higher intensity burns which reduce canopy cover have been shown to give competitive advantage to oaks by increasing the density relative to competitors such as red maple (Ducey et al. 1996; Swan 1970). Long term studies with recurrent 
low intensity fires have also shown the ability to more substantially alter forest composition and structure than a single low intensity fire without as great a risk as a single high intensity burn.

\section{Multiple Fires}

While single prescribed burns, particularly of low intensity, generally provide little benefit to oak regeneration and may even favor competing species in the understory, research on the use of long term recurrent burning has showed more promise. There is evidence that over an extended period of time, a commitment to repeated burning can provide a competitive advantage to oak species relative to less fire tolerant species and less vigorously sprouting competitors. Furthermore, long term studies show that such an approach has the potential to alter stand structure by reducing midstory and even overstory with a corresponding increase in light and the promotion of advanced reproduction. Naturally, results of long-term studies vary due to differences in fire frequency, region, and methodology, muddling strong definitive and widely applicable conclusions. Furthermore, oaks are not immune to the negative effects of fire, and a regime of too frequent burning will increase seedling mortality and ultimately decrease advance regeneration. Nonetheless, while not a guaranteed solution to the problem of oak regeneration, long-term repeated prescribed fires may be part of the larger solution.

On sites located in southern Ohio and eastern Kentucky, 3-5 fires over a 13 year span reduced the dominance of shade tolerant species while promoting oak and hickory in the sapling layer on dry sites. However, while more mesic sites also experienced an increase in oak and hickory seedling density following repeat burns relative to unburned sites, this was accompanied by an increase in many shade tolerant species as well, leaving ambiguity regarding the actual benefit to oak regeneration on higher quality sites (Hutchinson et al. 2012). Signell et al. (2005) found that National Guard Training Center sites with a 50-year history of frequent fires from 
training exercises had substantially lower densities of red maple in the overstory and greater densities of oak saplings in burned sites versus unburned sites. These differences were largely associated with decreased overstory and midstory density. A nine year study in Kentucky found prescribed fires applied twice or three times to be successful in reducing midstory density (Blankenship and Arthur 2006). Prescribed fires resulted in a 94\% initial decrease in red maple density and an increase in the density of oak seedlings (Blankenship and Arthur 2006). However, red maple sprouted prolifically over eight years and final sapling density was highest on the sites burned three times. While repeat burning was successful in opening up the forest floor for oak seedlings, the prominence of red maple on the site largely negated the potential benefits. In contrast, DeBord et al. (2011) integrated canopy treatments and two prescribed fires and found two burns to be an effective tool for reducing and maintaining low red maple densities over an eight year period. In areas with two prescribed fires, red maple density of medium sized stems was reduced $60 \%$ following an initial fire and $43 \%$ following a second. Red maple mortality in larger sapling classes showed a similar pattern though with greater percent reductions. No differences in seedling density of any species were present between treatments in stands receiving zero, two, and four burns in southern Ohio over a four year period (Hutchinson et al. 2005). However, large and small sapling densities were significantly lower on sites receiving burns, leading the authors to suggest continued burning in conjunction with other silviculural treatments to reduce mid and overstory density (Hutchinson et al. 2005).

Frequent fire can have negative impacts on oak regeneration when advanced reproduction lacks sufficient root mass to resprout repeatedly. Dey and Hartman's (2005) study of repeated fire in the Ozark Highlands of Missouri found post-fire survival to be related to basal diameter; survival decreased as each subsequent fire acted on a new cohort of seedling sprouts. Mortality 
of $2.54 \mathrm{~cm}$ black oak stems was $25 \%$ in stands receiving multiple burns in comparison with $10 \%$ on those receiving only one. Also in Missouri, Sasseen and Muzika (2004) showed multiple periodic burns reduce small oak seedling density over time.

Low intensity fires in the understory of hardwood forests have little effect on larger trees and therefore fail to increase infiltration of sunlight significantly enough to favor oaks. In instances where prescribed burning does not reduce density in the mid and overstory, it may to create light conditions necessary to promote the establishment of sufficiently large advance reproduction (Brose et al. 2006, Arthur et al. 2012). To create light conditions adequate to maximize growth of oak reproduction relative to shade intolerant competitors, overstory treatments, particularly shelterwood harvests, can be implemented.

\section{Shelterwood}

As previously noted, the maintenance requirement for oak seedlings is $2-5 \%$ full sunlight (Gottschalk 1994; Johnson et al. 2002; Rebbeck et al. 2011, Rebbeck et al. 2012). Growth increases with increasing levels of light up to 20-30\% full sunlight, after which, increased levels of light result in marginal if any increase in growth rates. Not only do oaks not respond to light beyond these levels, but such light intensity encourages the establishment of fast growing, shade intolerant species such as birch (Betula spp.) and yellow-poplar which are capable of overtopping and shading out even pre-established oak seedlings. Therefore the shelterwood method is employed to facilitate the growth and establishment of large oak advanced reproduction while maintaining sufficient canopy to curb the presence and growth of these shade intolerants. The shelterwood method is implemented through a series of two or three cuts: 1) a

preparatory cut to allow for crown expansion and acorn production and reduce low shade, 2) a second partial removal of the overstory and midstory to allow for establishment of advanced 
reproduction, and 3) a final overstory removal following this establishment to release reproduction (Hannah 1988, Johnson et al. 2002, Loftis et al. 1990, Nyland 2007). The extent to which overstory stocking is reduced prior to the final harvest varies by site quality and potential competition, but is generally between $70 \%$ and $30 \%$, with a lesser reduction on higher quality sites with a likelihood of more intense competition (Brose and Van Lear 1998, Dey et al. 1997b, Dey et al. 2008, Dey et al. 2010, Iverson et al. 2008, Johnson et al. 2002, Loftis et al. 1990, Schlesinger et al. 1993).

While it is a widely used prescription to promote oak regeneration, the shelterwood method should be understood as a flexible approach that can be modified for specific site and stand conditions and that success in creating conditions conducive to oak regeneration is variable. Brose (2011) examined the 8 year growth of planted acorns under control, preparatory cut, initial shelterwood cut, and final overstory removal conditions in an attempt to refine the management to environmental condition to seedling response relationship. The author found that growth and survival was indeed greatest under the high light conditions of the overstory removal followed by the next highest light conditions created by the initial shelterwood cut. However, when considering competitive status, the initial shelterwood followed by the preparatory cut were the most productive, with oaks dominating on 4 of 4 and 3 of 4 plots, respectively. Downs et al. (2011) compared the effectiveness of reducing stocking levels to $50 \%$ and $70 \%$ in releasing oak regeneration on stands in southern Ohio. Two years following the harvests, the authors found northern red oak seedling density to be highest on the $70 \%$ stocked site, with red maple, the dominant pre-treatment species, remaining so across all treatments and yellow-poplar density being highest on sites reduced to $50 \%$ stocking. This confirms the ability of an appropriate stocking reduction to increase oak while inhibiting shade intolerant species. However, the 
continued dominance of red maple suggests additional competition control may still be necessary. Loftis (1990), in a study in the Blue Ridge mountains, argued that midstory removal with a largely intact overstory was sufficient to stimulate small advanced reproduction while limiting competition from shade intolerants. Lorimer et al. (1994) found similar results in southwestern Wisconsin, where a midstory removal resulted in higher survival of underplanted oak seedlings and greater numbers of natural seedlings over five years relative to untreated plots. However, when examining a gradient of regeneration harvests in more diverse stands in northern Alabama with substantial existing shade tolerant component, Schweitzer et al. (2011) found reduction to $75 \%$ residual stocking and a midstory herbicide treatment had minimal and ephemeral effects on forest floor light levels and initiated a response in sugar maple reproduction. In the same study, treatments leaving 50\% and $25 \%$ stocking experienced substantial increases in yellow-poplar density. This abundance of yellow-poplar following shelterwood harvests with high potential to overtop oak reproduction was reported by Weigel and Johnson (2000) in southern Indiana and in other studies in eastern broadleaved forests (Loftis 1983; Dey et al. 2009; Jenkins and Parker 1998)

Ultimately, similar to prescribed fires, studies have shown the shelterwood method to exhibit varying levels of effectiveness in facilitating oak regeneration. Most success has occurred where small oak advanced reproduction is already present and the harvest enhanced growth (Loftis 1990; Graney 1999). In addition, the presence and vigor of competition, either in the form of pre-existing shade tolerants or fast growing shade intolerants seeding post-harvest, is a significant determinant of success. It is frequently the case that both are present, particularly on high quality sites, making additional competition control necessary. 


\section{Combinations}

Prescribed burns in association with shelterwood harvests have been shown to support oak regeneration on higher quality sites in-so-far as they reduce competition. In a high quality stand in the Virginia Piedmont, Brose and Van Lear (1998) found spring burns following the seed cut to favor oaks over red maple and yellow poplar reproduction. Iverson et al. (2008) found that two fires following a thinning resulted in greater oak density and a reduction in red maple and yellow poplar as well. However, competition was still substantial and the composition of advanced reproduction varied across the landscape. In southern Ohio, stands reduced by $20-30 \%$ of the initial basal area and receiving a single spring burn, did not provide oak reproduction a competitive advantage, but showed some evidence that continued burning may prove beneficial (Albrect and McCarthy 2006). In contrast, burned 0.5 ha forest openings in mesic hardwood stands in southern Wisconsin proved promising, experiencing an $80 \%$ decrease in sugar maple in comparison with an almost 50\% increase in northern red oak densities (Kruger and Reich 1997). This differs from the traditional shelterwood burn approach and suggests the possibilities of a prescribed burn - group selection management regimes where even-aged management is not feasible or desired.

Efforts to regenerate oak hinge on a given prescription's ability to create environmental conditions conducive to promoting establishment and growth of oak advanced reproduction relative to other species. Developing advanced reproduction can be a lengthy process and, as discussed above, cannot be guaranteed successful. Where natural reproduction is lacking, it may be augmented through artificial regeneration methods, specifically enrichment plantings and underplantings (Dey et al., 2008; Johnson et al., 2002). 


\section{Plantings}

Historically, the use of artificial regeneration of oaks has been infrequent and generally unsuccessful. As the absence of advanced reproduction became apparent, plantings were proposed as a suitable solution in some contexts (Sander 1971). While these early efforts were often ineffective, the continued difficulty of establishing advanced reproduction on some sites continues to promote research in supplementing natural regeneration through planting.

Addressing early failures, Johnson et al. (1986) provided a prescription for successful red oak plantings in the Missouri Ozarks. The authors advocate a four step procedure involving 1) pre-planting competitor control with herbicide, 2) establishment of a 55-65\% stocked shelterwood, 3) selection of large diameter ( $\geq 3 / 8$ inch) nursery stock, and 4 ) overstory removal three growing seasons following planting.

Quality seedling stock is essential to successful artificial regeneration. The most prevalent stock is $1+0$ bare root seedlings, though $2+0$ is not uncommon. Morphological characteristics are easily measured and are used as indicators of quality and vigor. Initial stem height has been shown to be a relatively poor indicator of seedling growth. Better indicators are those associated with root structure such as basal diameter and number of first order lateral roots (FOLR). While FOLR number is an often-used predictor of performance, more recent studies have found initial stem diameter to be the best indicator of success due to its correlation with root mass (Dey and Parker 1997b, Spietich et al. 2002, Spietich et al 2004, Thompson and Schultz 1995; Weigel and Johnson 2000). As a general rule, larger stock is preferable but factors such as shallow rocky soil, economic considerations, and management objectives also determine this choice. While Johnson et al.'s (1986) prescription called for at least $3 / 8^{\text {th }}$ inch stock, Spietich et al. (2002 and 2004) provides 11 year dominance probabilities for seedlings planted 
under shelterwoods, allowing for an estimation of cost per future competitive tree. This provides more flexibility in identifying stock appropriate for site conditions and management objectives. It is also useful guide when the size and quality of stock is limited by availability.

Once planted, maintaining adequate light for vigorous growth and controlling competition becomes paramount (Dey et al., 2008; Johnson et al., 2002; Schuler and Robinson, 2010). As a result, research on the performance of enrichment plantings tends to parallel studies on natural regeneration, both placing an emphasis on seedling response to various prescriptions. Establishing planted seedling beneath a full canopy tend to result in high mortality and low growth. These results bring to question the merit of the investment. In a two year study of underplanted red oak seedlings in Ontario, Dey and Parker (1997b) found the majority of seedlings in an uncut stand decreased in regard to number of first order lateral roots, stem diameter, and height. This suggests that planting even two years prior to shelterwood harvest places underplanted oaks at a competitive disadvantage (Dey and Parker, 1997b). In contrast, in Paquette et al.'s (2006) study of enrichment plantings for restoration of "impoverished" earlysuccessional stands, northern red oak seedlings planted under full canopy became sufficiently established to respond well to an initial shelterwood harvest 3 years later.

Seedlings planted under partial overstories or in stands where midstories have been removed to increase light availability perform better on the whole. In Ontario, Dey and Parker, (1997b) found this to be true of seedlings planted under a shelterwood compared to those planted under a full canopy. In stands receiving only a midstory removal Parrott et al. (2011) found black oak (Q. velutina) and white oak (Q.alba) exhibited better growth and survival rates when compared to control stands after 5 years. However, black oak survival was still only $32 \%$ and diameter growth $2.2 \mathrm{~mm}$. Examining enrichment plantings in clearcuts, two-aged stands, high 
grades, and controls, Oswalt et al. (2006) found high quality northern red oak seedlings to show high survival and positive growth on all but the control sites, with the clearcut showing the greatest, followed by the two-aged and high-graded stands.

The association of seedling success and overstory removal would appear to indicate planting following clearcuts as the most viable approach. However, as with natural reproduction, studies have found that enhancement plantings in clearcuts result in limited success as oak seedlings are overtopped by faster growing vegetation (Johnson et al. 2002; McGee and Loftis 1986). For success in clearcuts, sites must be of high enough quality to support the requirements of oak but low enough to limit heavy competition (Johnson et al., 2002). Addressing intense competition in clearcuts on higher quality sites, Schuler and Robinson (2010) examined the effects of planting exclusively high quality seedling stock with fertilization, weedmats, and herbicide. Despite the relatively intense management of individual seedlings, they experience slow growth and little positive treatment effects. The authors attributed this to possible intense below ground competition (Schuler and Robinson 2010). Post-clearcut enrichment plantings by McGee and Loftis (1986) were also unsuccessful despite competition control through herbicides.

While a proliferation of research on oak regeneration exists, there is a shortage of conclusive and converging evidence in support of a given solution or prescription. Certainly, basic tenets are well established: established advanced reproduction is essential prior to overstory removal, photosynthesis is maximized at approximately $20 \%$ full sunlight and plateaus near $30 \%$, and oaks' capacity for sprouting is a competitive advantage in disturbance regimes with frequent, low intensity burning. However, successful, predictable, and consistent application of these tenets in the forest is elusive. In short, despite all that is known and understood about oaks and the dilemma of regeneration, perhaps nothing is more certain and fundamental than that 
there is no panacea. Confounding factors persist at multiple scales, from aspect and slope position on a single ridge, to local deer densities, to differing communities of potential competitors at the ecoregion and physiographic province scale. Such factors complicate simple and direct comparison between studies and obfuscate the value and meaning of results.

Dey et al. (2008) address this in an argument for experiments comparing management regimes across broad scale environmental gradients such as eco-regions as well as the smaller scale gradients such as site quality. The authors provide a model study comparing the performance of red oak plantings under shelterwood harvests between sites in southern Indiana, the Missouri Ozarks, and the Boston Mountains of Arkansas. While initial seedling sizes and treatments were consistent; average dominance probabilities, the likelihood that an individual will become dominant or co-dominant over a given number of years, diverged across sites. The difference between communities associated with each region resulted in different principle competitors, specifically yellow-poplar in Indiana. Concomitantly, recommendations for the size and quantity of advanced reproduction needed to achieve a given stocking level differed as well (Dey et al., 2008; Spetich et al., 2002; Weigel and Johnson 2000). The authors suggest that studies such as this allow for the development more practical, consistent, and regionally specific findings and prescriptions for oak regeneration.

\section{Purpose}

This study seeks to further our knowledge of the response of northern red oak underplantings to forest management regimes across the environmental gradients of physiographic province and slope aspect, and treatments with and without fencing to remove the effect of deer. Management regimes included 1) control sites which were characterized by no harvesting or evident disturbance within 40 years, 2) a single prescribed burn, 3) repeat 
prescribed burns 5) diameter-limit cuts and 4) the seedcut of a shelterwood harvest. Burns and shelterwood harvests were chosen because they are frequently used to promote oak regeneration. Because of its widespread use and negative implications, its effects on oak advanced reproduction and the potential viability of enrichment planting in the absence of desirable reproduction merits study.

It was the working hypothesis that performance, as measured by growth and survival would increase with intensity of management and the associated increase in available light. Success would be greatest under the shelterwood harvest, followed by diameter-limit cuts, repeat burns, single burns, and finally control sites. Similarly, the more xeric Ridge and Valley sites with less dense mid and understories are inherently more conducive to the establishment of oak reproduction. Therefore, it was hypothesized that oaks would perform better on these sites relative to those in the Appalachian Plateau. However, it was expected that the effects of management regimes would not produce the same effects in the differing provinces. Subsequently, interactions between management regime and physiographic province were expected to be the most important drivers of seedling performance. It was expected that the exclusion of deer by fence, would provide protection from browse and result in improved seedling performance.

While the factors of management regime, physiographic province, and aspect implicitly include light to one degree or another, this study also more closely and directly examines the relationship between light and seedling performance as well as the association between light and forest structure. 


\section{METHODS}

\section{Study Area}

Study sites were located throughout east-central West Virginia, southern Ohio, and eastern Virginia (Figure1). Individual sites were on multiple ownerships including George Washington National Forest, Wayne National Forest, Zaleski State Forest $(\mathrm{OH})$, private industrial lands, and properties owned by non-industrial private forest (NIPF) landowners.

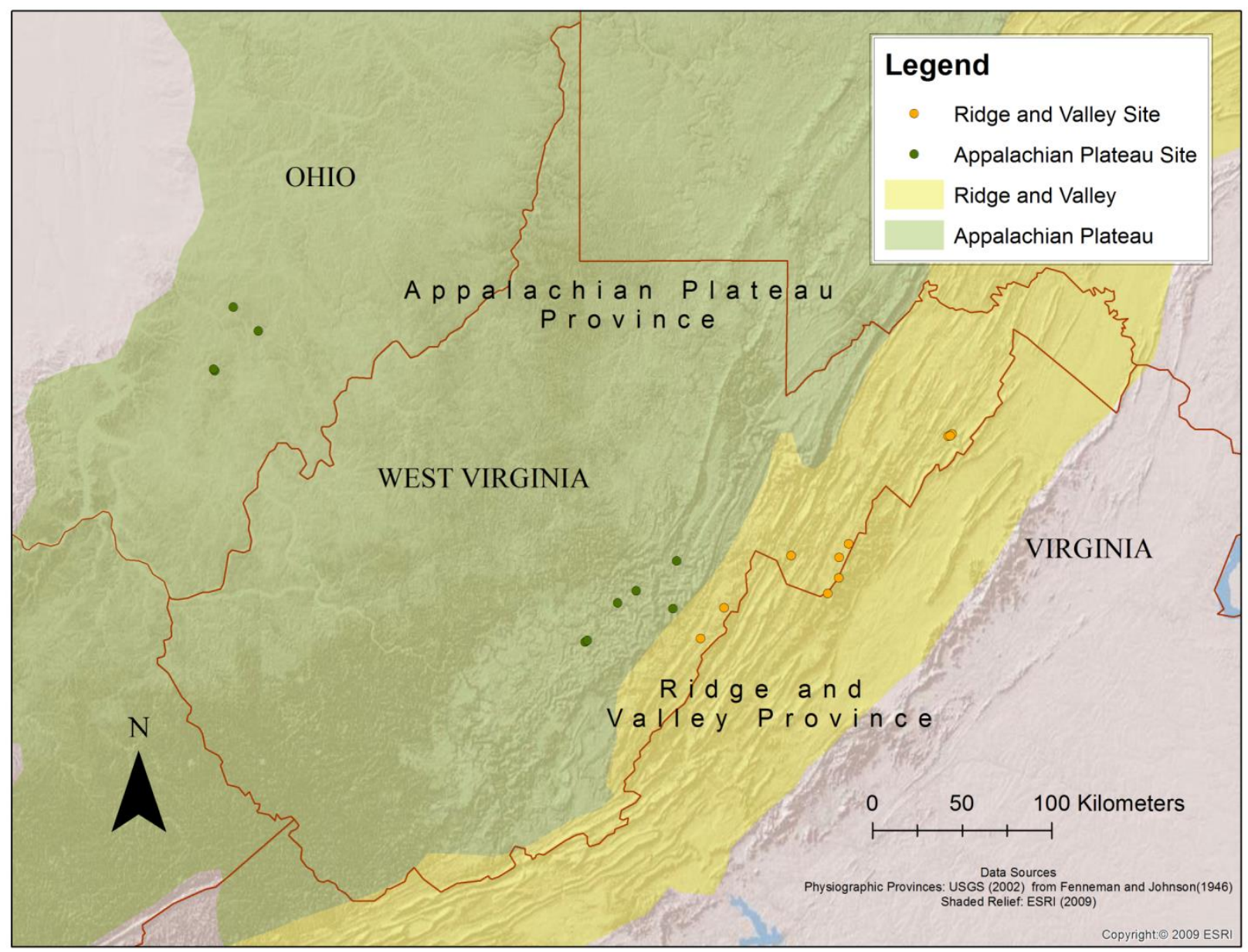

Figure 1. Study site locations within the Appalachian Plateau and Ridge and Valley physiographic provinces 


\section{Physiography, Soil and Climate}

\section{Appalachian Plateau}

The Appalachian Plateau physiographic province covers the western portion of the study area, including the majority of West Virginia and eastern Ohio. It is bounded to the west by the Central lowlands province and to the east by the Ridge and Valley province.

Control sites within the province included Desert Branch 1 (DB1) and Desert Branch 2 (DB2) in Monongahela National Forest. Single burn sites included Rich Hollow East (RHE) and Rich Hollow West (RHW) in Zaleski State Forest. Repeat burns were represented by Big Bailey (BB) in Wayne National Forest. Sites receiving a diameter-limit cut treatment consisted of Painter (PNT) and Clover Lick (CL) in Randolph and Pocahontas Counties, WV, respectively. Shelterwood sites included Gore-Greendale (GG) in Wayne National Forest and the Dilly Fork (PCDF) and Big Run (PCBR) on Plum Creek property in Nicholas County, WV.

The topography of the Appalachian Plateau is characterized by highly dissected hills and mountains, steep slopes, and numerous narrow valleys creating a dendritic drainage pattern (USFS 1994). Forests types are predominantly mixed mesophytic-oak with components of oakhickory, oak-pine, and hemlock stands (Eyre 1980, USFS 1994). The climate is warm and humid with precipitation of roughly $100 \mathrm{~cm}-150 \mathrm{~cm}$ per year and mean annual temperature range of $4-12^{\circ} \mathrm{C}$ (USFS 1994). Mean annual temperatures and precipitation for sites was estimated using National Climate data from nearby weather stations. The station for Athens, $\mathrm{OH}$ reported mean annual precipitation and temperature of $100 \mathrm{~cm}$ and $11^{\circ} \mathrm{C}$, respectively. Data from the Richwood USGS climate station reported an estimated mean annual temperature of $9.67^{\circ} \mathrm{C}$ for the area that includes the PCDF, PCBR, DB1, DB2, PNT, and CL sites. Mean annual precipitation in the Richwood area was approximately 137cm (NOAA 2012). 
Silt-loams are the dominant soil type within the province. Soils present on Appalachian Plateau sites include the Gilpin, Macove, Buchanan, Wilkes, Snowdog, Westmoreland-Gurnsey, and Steinsburg-Gilpin series. These soils are derived from sandstone, siltstone and shale parent material and are characterized as being very to moderately deep, well drained to moderately well drained, and having moderate to slow permeability. Overall, these soils are mesic to sub-mesic and of moderately high productivity, site index $21.3-24.4 \mathrm{~m}$ for northern red oak, base age 50 (NRCS 2012).

\section{Ridge and Valley}

The Ridge and Valley province occupies the eastern portion of the study area. The province is bounded to the west by the Appalachian Plateau's Allegheny Front and by the Blue Ridge Mountain province to the east. Ridge and Valley control sites included Evick Knob (EK) and Sandy Ridge (SR) in George Washington National Forest. Single burn sites included Chestnut Ridge (CR) in Monongahela National Forest and Hall Spring (HS) in George Washington National Forest. Repeat burns were located in George Washington National Forest and represented by North River (NR) and Little Fork (LF). Sites receiving a diameter-limit cut treatment consisted of Jeannie (JN) and Grimes (GRM) in Pocahontas County, WV. Shelterwood sites included Sandy Ridge 2 (SR2) and Sandy Ridge 710 (SR710) in George Washington Jefferson National Forest (Figure 1)

Ridge and Valley topography is dominated by long, parallel, southwest- northeast oriented ridges and broad valleys produced through orographic folding. Oak-hickory and oakpine are the predominant forest types (Eyre 1980, USFS 1994). This province lies in the rain shadow of the Allegheny Front, resulting in a drier climate with a mean annual precipitation ranging from 75 to $115 \mathrm{~cm}$ throughout the provinces. Temperatures across the province are 
comparable to those seen on the Appalachian Plateau (USFS 1994). Specific to this study, the Franklin, WV and Harrisonburg, VA weather stations are representative of the EK, JN, HS, LF, $\mathrm{CR}$, and GRM sites. Mean annual temperature is $11.3^{\circ} \mathrm{C}$ and mean annual precipitation is 91.5cm for the area. The Ridge and Valley sites of SR, SR2, and SR710 are nearby Moorefield, WV and Front Royal, VA. Mean annual temperature and precipitation for this area is $12.5^{\circ} \mathrm{C}$ and $103.9 \mathrm{~cm}$, respectively (NOAA 2012).

Ridge and Valley sites include soils of the Calvin, Cateach, Dekalb, Berks, Opequon, Faywood, Schaffenaker-Drall, Lehew-Hazleton-Dekalb, and Shouns series. Again, these soils are of sandstone, siltstone, and shale origin. Generally, soils here are shallower than those of the Appalachian Plateau and classified as moderately deep. They tend to be well drained to excessively well drained with moderate to rapid permeability making for more xeric, lower productivity sites (NRCS 2012). Site indices for these soils range from 18.3-21.3m for northern red oak, base age 50 .

\section{Site Selection and Layout}

Study sites were selected by location within the Appalachian Plateau and Ridge and Valley provinces (Fenneman 1938) and existing management regime. Initial plans called for two replications of each management regime within each province for a total of twenty sites (2 sites/province $\times 5$ regimes/province $\times 2$ sites/regime $=20$ sites $)$. However, final implementation resulted in three replicates of the shelterwood treatment and only one repeat burn replicate within Appalachian Plateau. 


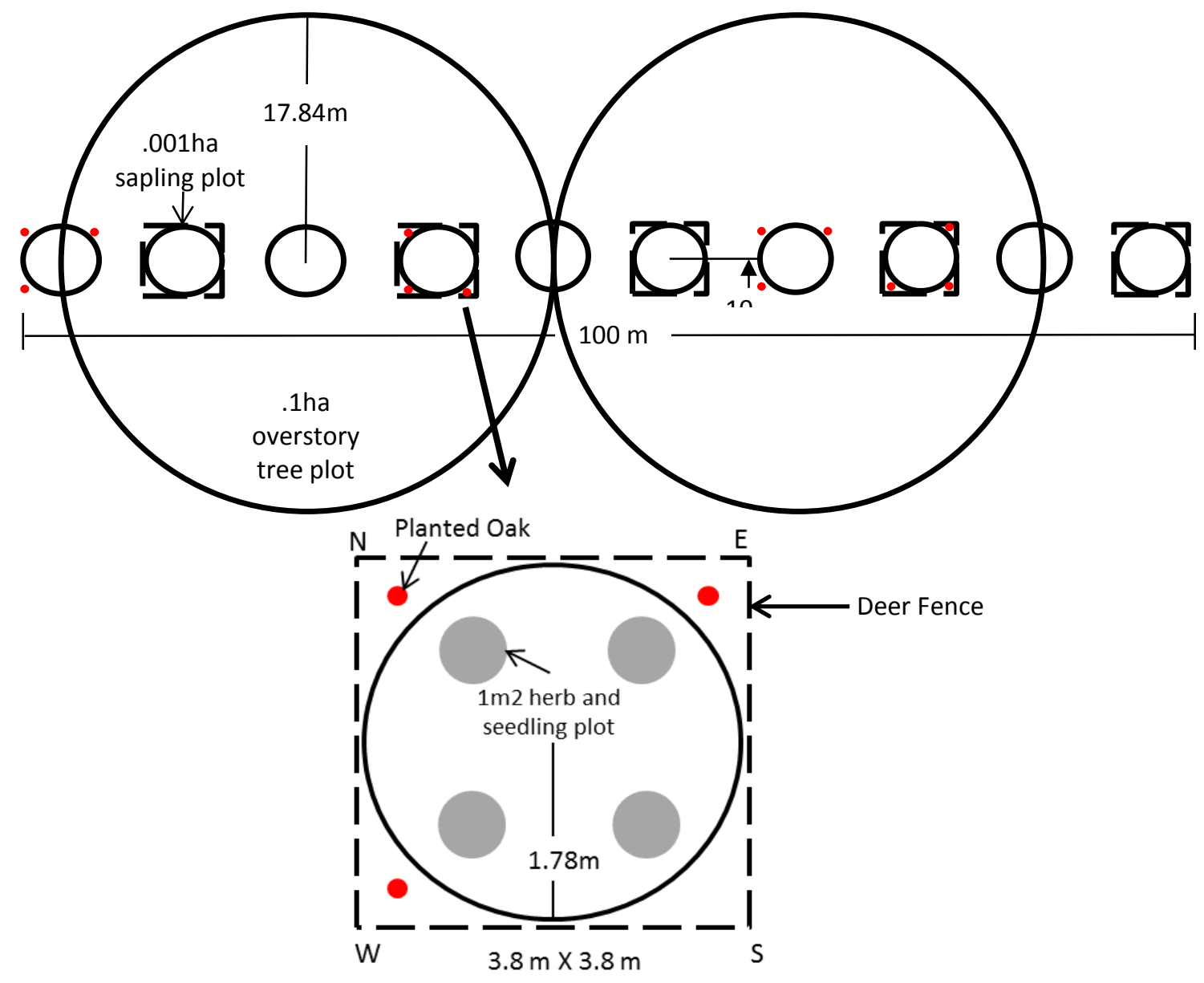

Figure 2. Transect and plot layout for vegetation inventory and seedling planting.

Each site consisted of two 100-meter transects, one each on east-northeast and southsouthwest aspect, making a total of 40 transects (Figure 2). Actual aspect of east-northeast aspects ranged between 350 and 176 degrees azimuth. South-southwest aspects ranged between 182 and 280 degrees azimuth. This design provided two replicates of each physiographic province, management regime, aspect combination. Ten circular plots of 0.001 ha were established along transects. Six of these plots were selected for planting oak seedlings. Of these 
six plots per transect, three were randomly selected and fenced using standard $1.2 \mathrm{~m}$ high woven wire fencing (Figure 2). Fences were constructed around plots in a $3.8 \times 3.8 \mathrm{~m}$ square. It is recognized that it is within a deer's ability to jump over fences of this size. However, given the relatively small enclosure it was determined that this height posed a sufficient deterrent to deer. Three $1+0$ oak seedlings were planted at the corner of each plot in alignment with the cardinal directions. Initial designs called for all ten plots per transect to be planted with 4 seedlings per plot. This was adjusted due to time constraints during planting. Therefore, those transects planted first included a greater number of seedlings, resulting in a total of 266 plots and 798 seedlings.

Seedlings were purchased from Clements State Tree Nursery in West Columbia, West Virginia in March 2011 and stored at $5^{\circ}$ Celsius until planting. Price of seedlings as of April 2012 is $\$ 250.00$ per 1000 . Seedlings were of unimproved stock and grown from seed collected throughout West Virginia and southern Ohio. As this is the extent of the study area, uncertainty in precise provenance was deemed acceptable. Planting was conducted during April and May 2011 by Dr. Huebner and a USDA Forest Service crew. During fieldwork, seedlings were kept damp and shaded. The spring of 2011was cool and wet, with much of the study area seeing above average rainfall in April and May making for good planting conditions (NOAA 2012).

Measurements of diameter and height were taken immediately after the spring planting. Summer measurements of height, diameter, indication of deer browse (presence/absence), and survival were taken twice more during June-August. End-of-first-growing-season measurements were taken during October and November 2011. Two mid-growing season measurements were taken during June through August. Final end-of-growing season measurements were taken October-December of 2012. 


\section{Data Collection}

Initial vegetation inventories were taken for each transect in 2010. Field crews estimated percent cover of understory vegetation including all herbs, shrubs, vines, and seedlings on four $1.0 \mathrm{~m}^{2}$ within ten 0.001 ha plots per transect. Saplings $(<10 \mathrm{~cm} \mathrm{dbh}$ and $\geq 1 \mathrm{~m}$ height $)$ were tallied by species on these 0.001 ha plots. Overstory trees $(\geq 10 \mathrm{~cm}$ at $\mathrm{dbh})$ were tallied by species and dbh was recorded for two 0.10 ha plots per transect. Overstory plots shared plot centers with either the forth and eight or third and seventh of the 10 square meter sapling plots (Figure 3).

Hemispheric photographs were taken from each plot center and HemiView ${ }^{\circledR}$ software used to measure and analyze the degree of canopy closure and light infiltration. Global site factor (GSF), the proportion of direct and diffuse radiation on a site relative to that in a completely open site, was computed using HemiView ${ }^{\circledR}$ and used in subsequent analyses.

Diameters of planted seedlings were measured at $2.54 \mathrm{~cm}$ above ground level using calipers. First year growth results appeared overwhelmingly negative and raised suspicion of the validity of measurements. After tests, it was determined that differences in the amount of pressure with which different individuals applied the calipers and slight variations in the location of measurement in the stem were enough to introduce large errors relative to the small amount of diameter growth of the planted seedlings. Care was taken to standardize pressure applied and following the first summer all measurements were taken by a single individual. Variations in the height on the stem at which diameter was measured were attributed to possible human error but also the settling, erosion, and deposition of soil around stems. As a result of the variation in initial measurements, the estimated diameter growth of the planted seedlings had an error component that could not be calculated. However, there was no evidence to suggest that errors 
were biased toward a particular treatment and therefore trends in diameter growth were included in analysis.

Height measurements were taken to the apical bud on the tallest branch if it was present and live. For seedlings with dead or browsed tops, the height to the terminal live bud of the most dominant branch was recorded, with that branch being adjusted, but not stretched, perpendicular to ground line. Survival was recorded as binary (living/dead) as was evidence of deer browsing (browse/no browse). However, deer browse was not recorded on dead seedlings as it was difficult to determine with certainty whether a stem was browsed or broken after death. This resulted in detection of browse being biased toward sites with high overall survival. Therefore, browse data was not used in the analysis.

\section{Initial Conditions of Management Regimes}

As sites were selected for preexisting management regimes, some variability in site history and disturbance was present (Table 1). However, variability was reflective of the practical reality that sites and treatments can be highly variable. Control sites had not experienced a major disturbance or management within the past 60 years. All past prescribed burns had occurred in spring. Single burn sites had experienced one prescribed fire within the past 10 years at the time of planting. RHE and RHW were burned in 2006. CR and HS were burned in 2010 and 2008 respectively. Repeat burn sites had received two or more prescribed fires within 10 years prior to planting. Of these, BB received three burns over that time period, the most recent occurring in April, 2011. The LF site was burned in spring of 1998 and 2008. NR experienced spring burns in 2003 and 2009. 
Table 1. Management history and specifications of study sites

\begin{tabular}{|c|c|c|c|}
\hline $\begin{array}{l}\text { Management } \\
\text { Regime }\end{array}$ & Site $^{a}$ & Rx guideline & $\begin{array}{c}\text { Year of } \\
\text { treatments(s) }\end{array}$ \\
\hline & ------- & achian Plateau Sites------ & \\
\hline \multirow{2}{*}{ Control } & DB1 & none & - \\
\hline & DB2 & none & - \\
\hline \multirow{2}{*}{ Single Burn } & RHE. & Spring Burn & 2009 \\
\hline & RHW. & Spring Burn & 2006 \\
\hline Repeat Burn & BB & Spring Burns & 2004,2009, 2011 \\
\hline \multirow{2}{*}{ DLC } & CL & $\begin{array}{c}45.7 \mathrm{~cm} \text { Merchantable } \\
\text { 35.6-40.6cm Non-merch }\end{array}$ & 2006 \\
\hline & PNT & $\begin{array}{l}45.7 \mathrm{~cm} \text { Merchantable } \\
35.6-40.6 \mathrm{~cm} \text { Non-merch }\end{array}$ & 2006 \\
\hline \multirow{3}{*}{ Shelterwood } & GG & 50 Residual BA & 2008 \\
\hline & PCBR & 50 Residual BA & $2007 / 2008$ \\
\hline & PCDF & 50 Residual BA & 2007 \\
\hline & $-\cdots-\cdot-$ & ge and Valley Sites------ & \\
\hline \multirow{2}{*}{ Control } & EK & none & - \\
\hline & SR & none & - \\
\hline \multirow{2}{*}{ Single Burn } & $\mathrm{CR}$ & Spring Burn & 2010 \\
\hline & HS & Spring Burn & 2008 \\
\hline \multirow{2}{*}{ Repeat Burn } & LF & Spring Burns & 1998,2008 \\
\hline & NR & Spring Burns & 2003,2009 \\
\hline \multirow{2}{*}{ DLC } & GRM & 40.6cm All (No Pine) & 2009 \\
\hline & JN & 45.7cm Merchantable & $2007 / 2008$ \\
\hline \multirow{2}{*}{ Shelterwood } & $\mathrm{SR} 2$ & $25 \%$ Residual & 2008 \\
\hline & SR710 & $25 \%$ Residual & 2008 \\
\hline
\end{tabular}

\footnotetext{
${ }^{a}$ Site names and the associated abbreviation are found in the Physiography, Soil, and
} Climates discussion

Diameter-limit cuts varied in respect to specified minimum diameter and cutting of nonmerchantable trees. At CL and PNT in the Appalachian Plateau, guidelines called for all merchantable timber $>45.7 \mathrm{~cm}$ dbh to be harvested and non-merchantable trees between $35.6 \mathrm{~cm}$ 
and $40.6 \mathrm{~cm}$ dbh to be removed or deadened. Guidelines at GRM called for all hardwoods $35.6 \mathrm{~cm}$ dbh to be cut and pines left standing. On JN, only merchantable timber $45.7 \mathrm{~cm}$ dbh was to be harvested. JN was harvested over the course of 2007-2008. All other diameter-limit cut sites were harvested in 2009. Shelterwood sites had received the seed cut of the shelterwood system in 2007 and 2008. Of these, GG, PCDF, and PCBR on the Appalachian Plateau were reduced to $50 \%$ of the original basal area while SR2 and SR710 in the Ridge and Valley were reduced to $25 \%$ residual basal area (Table 1$)$.

Table 2. Mean basal area ( $\left.\mathrm{m}^{2} / \mathrm{ha}\right)$, sapling and seedling density (stems/ha) and understory vegetation (\% cover) reported by study site

\begin{tabular}{cccccc}
\hline $\begin{array}{c}\text { Management } \\
\text { Regime }\end{array}$ & Site & $\begin{array}{c}\text { Basal Area } \\
\left(\mathbf{m}^{2} / \mathbf{h a}\right)\end{array}$ & $\begin{array}{c}\text { Sapling } \\
\text { Density }\end{array}$ & $\begin{array}{c}\text { Seedling } \\
\text { Density }\end{array}$ & $\begin{array}{c}\text { Understory } \\
\text { Cover }(\%)\end{array}$ \\
\hline \multirow{2}{*}{ Control } & DB1 & 30.2 & 3,100 & 93,875 & 5.6 \\
& DB2 & 37.6 & 2,950 & 79,875 & 7.3 \\
Single Burn & RHE. & 29.9 & 550 & 78,875 & 5.9 \\
Repeat Burn & RHW. & 31.8 & 400 & 41,750 & 5.9 \\
& BB & 22.1 & 2,350 & 37,500 & 7.0 \\
DLC & CL & 17.0 & 1,700 & 206,875 & 10.8 \\
& PNT & 13.8 & 1,750 & 43,750 & 19.5 \\
\multirow{2}{*}{ Shelterwood } & GG & 19.3 & 4,050 & 71,375 & 12.2 \\
& PCBR & 12.7 & 1,050 & 109,375 & 16.7 \\
& PCDF & 10.8 & 9,050 & 341,750 & 53.1 \\
\hline
\end{tabular}

Ridge and Valley Sites

\begin{tabular}{cccccc}
\hline \multirow{2}{*}{ Control } & EK & 24.8 & 250 & 50,250 & 6.1 \\
& SR & 28.5 & 100 & 21,250 & 2.3 \\
Single Burn & CR & 25.0 & 200 & 48,250 & 3.3 \\
& HS & 27.7 & 150 & 26,250 & 10.0 \\
\multirow{2}{*}{ Repeat Burn } & LF & 30.2 & 650 & 86,375 & 14.6 \\
& NR & 24.8 & 400 & 36,000 & 14.2 \\
DLC & GRM' & 19.0 & 200 & 57,625 & 14.3 \\
\multirow{2}{*}{ Shelterwood } & JN & 25.5 & 0 & 261,500 & 1.1 \\
& SR2 & 1.6 & 350 & 48,000 & 16.5 \\
& SR710 & 3.2 & 350 & 76,842 & 16.9 \\
\hline
\end{tabular}



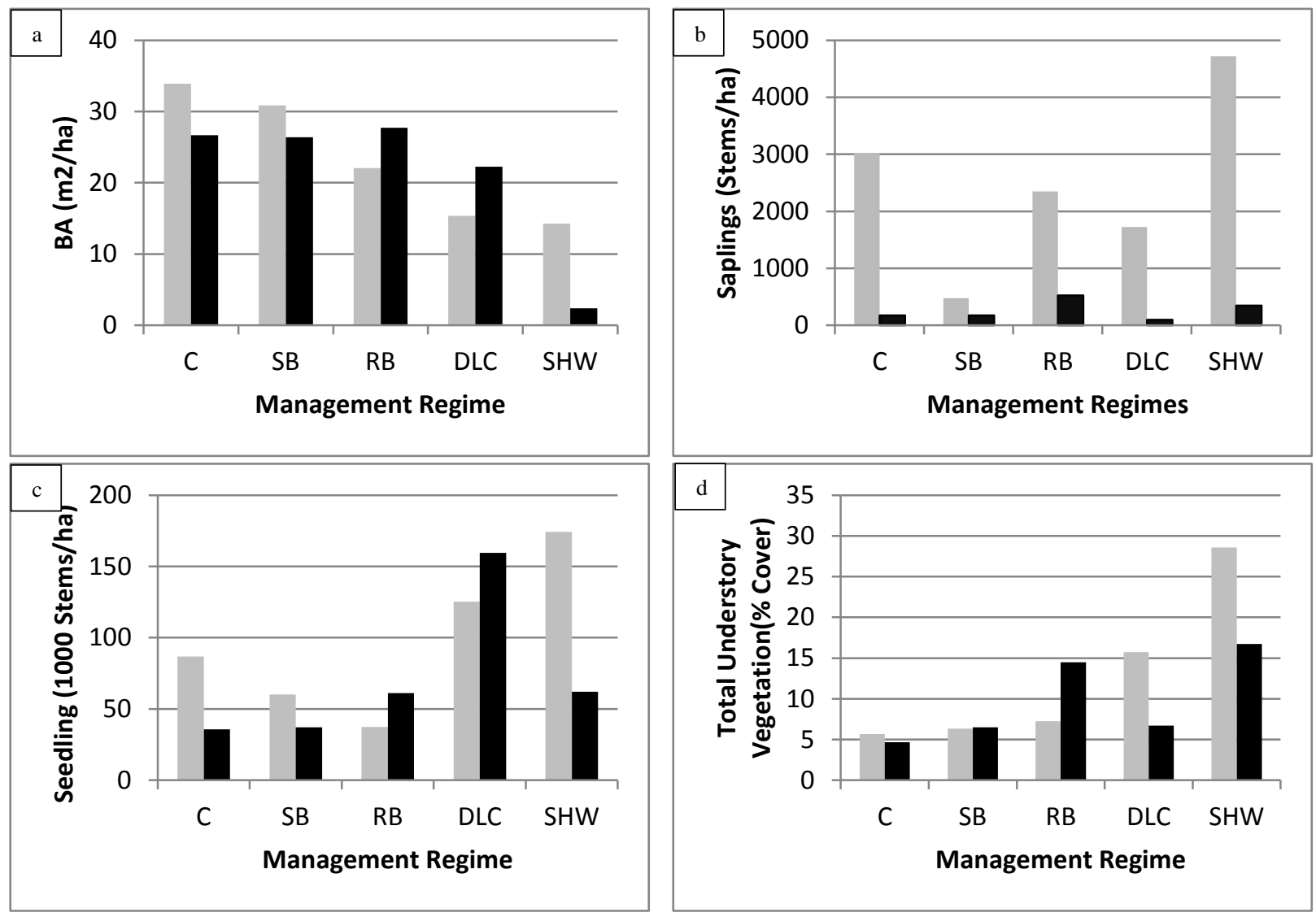

Ridge and Valley

Appalachian Plateau

Figure 3. a) Basal area, b) sapling density, c) seedling density and d) non-tree understory vegetative cover present at the study establishment.

Forest structure, composition, and subsequent light levels varied by management regime and physiographic province. Basal area differed as expected. On average, highest basal area was found on control sites, followed by single burns, repeat burns, diameter-limit cuts, and shelterwood harvests (Table 2, Figure 3). Sapling density did not show an equally clear pattern across management regimes, though density was generally higher in shelterwood harvests. A stronger pattern is seen between physiographic provinces, as the Appalachian Plateau sites had a denser 
sapling layer regardless of management (Table 2, Figure 3). Seedling density was highest under the DLC and shelterwood regimes and total understory vegetation generally increased with increased disturbance (Table 2, Figure 3). Information about species composition by basal area, sapling layer, seedling layer, and non-tree understory vegetation is presented in Appendices A, B, $\mathrm{C}$, and $\mathrm{D}$, respectively.

\section{Control}

Mean basal area of $30.3 \mathrm{~m}^{2} /$ ha on control sites was highest among all management regimes. Values ranged from $37.6 \mathrm{~m}^{2} /$ ha on DB1 in the Appalachian Plateau to $4.81 \mathrm{~m}^{2} / \mathrm{ha}$ at EK in the Ridge and Valley. Basal area was also higher on average in the Appalachian Plateau at $33.9 \mathrm{~m}^{2} /$ ha. While oak is a major component of these stands, yellow-poplar and sugar maple were as or more dominant. Control sites in the Ridge and Valley averaged $27.1 \mathrm{~m}^{2} /$ ha with oak accounting for greater than $70 \%$. On both sites a notable component of shortleaf and Virginia pines were also present.

Sapling densities of $>3,000$ stems/ha on Appalachian plateau sites were dominated by large numbers of shade tolerant species, particularly sugar maple. In contrast, sapling density was low in the Ridge and Valley. The relatively high seedling density of 86,875 stems/ha in the Appalachian Plateau was largely oaks. Ridge and Valley densities were low, dominated by red maple. Percent cover of non-tree understory vegetation was low on all control sites regardless of province.

\section{Single Burn}

Mean basal area across all single burn sites was $28.6 \mathrm{~m}^{2} /$ ha with a range of $31.8 \mathrm{~m} 2 / \mathrm{ha}$ at RHW to $25 \mathrm{~m}^{2} /$ ha on CR. Sites within the Appalachian Plateau averaged $30.85 \mathrm{~m}^{2} /$ ha while those 
in the Ridge and Valley average $26.4 \mathrm{~m}^{2} / \mathrm{ha}$. Yellow-poplar, oak, and sugar maple are most dominant within the Appalachian Plateau. Within the Ridge and Valley, oaks remain dominant with a minor component of pine at HS and red maple at CR.

Mean sapling density was low on all single burn sites, though higher in the Appalachian Plateau (>400stems/ha) than Ridge and Valley. Herbaceous and woody understory cover was $6.43 \%$ on single burn sites and remained low across provinces. Seedling density on these sites ranged from 26,000 to 78,000 stems/ha.

\section{Repeat Burns}

Repeat burn sites averaged $25.7 \mathrm{~m}^{2} / \mathrm{ha}$ in basal area. The lone repeat burn site in the Appalachian Plateau province, BB, had the lowest basal area at $22.8 \mathrm{~m}^{2} / \mathrm{ha}$. Mean basal area of repeat burn sites within the Ridge and Valley province was $27.5 \mathrm{~m}^{2} / \mathrm{ha}$, with LF representing the highest at $30.2 \mathrm{~m}^{2} / \mathrm{ha}$. Sugar maple and oak were the dominant species on BB. Oak were also dominant on the Ridge and Valley repeat burns, though sugar maple and red maple constituted noteworthy components at LF.

Sapling density on repeat burn sites was low. The sapling layer was most developed on $\mathrm{BB}$, with 2,250 stems/ha of predominantly sugar and red maple. Red and sugar maple were also prevalent in the Ridge and Valley, particularly LF. Density of 61,187 stems/ha on these sites was greater than BB as well as the control and single burn sites. The seedling layer was dominated by shade tolerant species including red maple and sugar maple. Percent herbaceous and woody understory vegetation cover was greater than on control and single burn sites, averaging $12 \%$. 


\section{Diameter-Limit Cuts}

Not surprisingly, basal area on diameter-limit cut sites varied greatly in conjunction with specific harvest guidelines. Mean basal area among all diameter-limit cuts was $18.8 \mathrm{~m}^{2} / \mathrm{ha}$. The highest basal area was $25.47 \mathrm{~m}^{2} /$ ha at $\mathrm{JN}$. Notably, this site had highest minimum diameter and had been harvested one year prior to others. The lowest basal area was $13.76 \mathrm{~m}^{2} / \mathrm{ha}$ at PNT in the Appalachian Plateau. Because harvest guidelines, rather than site province appeared as the primary driver of basal area, the pattern between provinces ran counter to that observed on control and burn sites. Diameter-limit cut in the Ridge and Valley averaged a basal area of $22.24 \mathrm{~m}^{2} /$ ha, relative to $15.37 \mathrm{~m}^{2} /$ ha found on Appalachian Plateau sites. Composition was variable as well. Oaks were dominant on PNT, JN, and to a lesser extent GRM, but only a minor component of CL, where sugar maple was the dominant species. Red maple was a substantial component on JN and Pines and hemlock on GRM.

Mean sapling density of 1,750stems/ha on Appalachian Plateau were predominantly shade tolerant, including sugar maple, striped maple, and American beech. Sapling density in the Ridge and Valley was low at 100 stems/ha. Seedling densities were substantially higher on diameter-limit cuts than control and burn sites, averaging 125,312 stems/ha in the Appalachian Plateau and 159,562 stems/ha in the Ridge and Valley. Red maple densities were high overall, especially in the Ridge and Valley. Shade intolerant species including sassafras (Sassafras albidum) and sweet birch (Betula lenta) were prevalent on the Appalachian Plateau. Percent herbaceous and woody understory vegetation cover was variable, ranging from $22 \%$ at PNT to $0.5 \%$ at $\mathrm{JN}$. 


\section{Shelterwood}

Basal area varied greatly on shelterwood sites. While the average of all sites was $9.53 \mathrm{~m}^{2} /$ ha, it ranged from $1.59 \mathrm{~m}^{2} / \mathrm{ha}$ on SR2 to $19.33 \mathrm{~m}^{2} / \mathrm{ha}$ on GG. Due to differing target residuals, a stark difference is present between the Allegheny Plateau sites, averaging $14.28 \mathrm{~m}^{2} / \mathrm{ha}$, and those in the Ridge and Valley, averaging $2.41 \mathrm{~m} 2 / \mathrm{ha}$. Red maple and black cherry were the predominant trees left on PCBR and PCDF. Oaks were the dominant component on GG followed by yellow-poplar. On the Sandy Ridge sites oaks were a substantial component, along with red maple on SR710.

Maximum sapling density among shelterwood sites was 10,500stems/ha on PCDF in the Appalachian Plateau. This was largely the product of high densities of shade intolerant species, specifically birch, sassafras, and pin cherry. On GG, the shade tolerant musclewood (Carpinus caroliniana) and black gum (Nyssa sylvatica) were primarily responsible for the 5,000stems/ha. Seedling density was highest on shelterwood sites, averaging 174,167 stems/ha in the Appalachian Plateau and 62, 051 stems/ha in the Ridge and Valley. Red maple and black and pin cherry were most prevalent in the Appalachian Plateau sites, while red maple, black gum, oaks and shade intolerant yellow-poplar and sassafras, were prevelent on Ridge and Valley sites. Percent herbaceous and woody understory vegetation cover was also highest under the shelterwood regime at $22.7 \%$. Blackberry was a primary component of the understory.

\section{Statistical Analysis}

All statistical analyses were carried out using SAS $9.3^{\circledR}$ statistical software. As plots were the experimental units, response variables were averaged at the plot level for tests. Initial diameter and height varied; therefore, relative growth (total growth/initial size) was used to account for any differences in total growth associated with initial size of seedlings. Prior to 
statistical tests, dependent and independent variables were assessed for normal distribution.

Those which were not normally distributed received log, arcsine-square root, square root, and squared transformations. The transformed variables were visually compared and that transformation which best approached normality was used (Table 3).

Table 3. Variables and the associated transformation.

\begin{tabular}{lc}
\hline \multicolumn{1}{c}{ Variable } & Transformation \\
\hline Relative Diameter Growth & Square root ${ }^{\mathrm{a}}$ \\
Percent Survival & Arcsine-square root \\
Global Site Factor & Arcsine-square root \\
Sapling Density & $\log +1$ \\
Seedling Density & $\log +1$ \\
Interfering Vegetation Cover & $\log +1$ \\
Total Non-tree Understory Cover & $\log +1$ \\
\hline${ }^{\mathrm{a} A}$ contstant of 0.5 was added to the original value to \\
eliminate negative values before transformation
\end{tabular}

\section{Assessment of Physiography, Management Regime, Aspect, and Fencing}

Mixed linear models were tested using the MIXED procedure in SAS. Fixed effects included physiographic province, management regime, aspect, and fencing. Site and plot factors were included in models as random effects. Relative diameter growth, relative height growth, and average survival rate were response variables.

Initially, linear models including all main effects and all possible interactions were run. Therefore, following these saturated models, a reduced model including only main effects and interaction effects with $p$-value $\leq 0.1$ was run. This latter model was the final model on which inferences were made. Statistical significance was assessed at the alpha $=0.05$ level. Normality of 
residuals and homogeneity of variances were visually assessed and used to validate model assumptions. Final models tested were:

$$
\begin{gathered}
S=\mu+G+P+M+S(M)+A+F+P L(F, A, M, P)+P \times M+P \times F+M \times A+M \times F+P \times M \times A \\
D=\mu+G+P+M+S(M)+A+F+P L(F, A, M, P)+P \times F+M \times F+P \times M \times F \\
H=\mu+G+P+M+S(M)+A+F+P L(F, A, M, P)+P \times A+M \times A
\end{gathered}
$$

Where $\quad S=$ Survival

$D=$ Square root transformed relative diameter growth

$H=$ Relative height growth

$\mu=$ Overall mean

$G=\mathrm{GSF}$

$P=$ Physiographic province

$M=$ Management regime

$S(M)=$ Site nested within management regime

$A=$ Aspect

$F=$ Fence

$P L(F, A, M, P)=$ Random effect Plot nested within Fence, Aspect,

Management Regime, and Physiographic Province

Post hoc tests were carried out on significant main effects and interactions. This was done through pairwise comparisons of least-square mean estimates obtained using the LSMEAN statement and PDIFF option. P-values were adjusted with the Tukey-Duncan adjustment to control for type I experiment-wise error. Only simple interactions, those in which only one factor differed between estimates, were tested per recommendation in Littell et al. (2002). For example, if considering the Regime $\mathrm{x}$ Fence interaction, Control-Fenced versus DLC-Fenced is a simple interaction which would be tested, while Control-Fenced versus DLC-Unfenced is not. The absence of a replicate of repeat burns in the Appalachian Plateau resulted in non-estimable least square means for the repeat burn management regime and Appalachian Plateau province 
factor levels. Therefore, all sites of the repeat burn management regime were removed from the analysis of fixed effects.

\section{Assessment of Environmental Variables}

Simple linear regression was used to test the effect of light on seedling growth. To assess the relationship between survival and light, logistic regression was conducted on plots designated as either stocked (having at least one surviving planting at the end of year two) or unstocked (having no surviving seedlings at the end of year two). The association of stand structure and light was assessed using multiple linear regression and the STEPWISE variable selection method. AIC was designated as the selection criteria and a $P$-value of 0.15 was set as the upper limit for a factors inclusion in the model. Repeat burn sites were included in tests for the effects of light on seedling vigor as well as tests for the effects of stand structure on light. 


\section{RESULTS}

\section{Fixed Effects and Seedling Vigor}

Analysis revealed significant differences in seedling growth and survival due to main effects as well as interactions. Because analysis was carried out on relative growth and diameter growth and survival were transformed, values are not easily interpreted. Therefore, though statistical tests were carried out on transformed values and adjusted least square means, unadjusted and non-transformed means and differences are reported in the following tables and text to aid in interpretation.

\section{Survival}

Following two growing seasons, the overall survival rate was 58\%. Non-transformed percent survival of each main factor level is presented in Table 4 .

Table 4. Non-transformed mean percent survival and standard error ( ) by levels of main factors

\begin{tabular}{lll}
\hline \multicolumn{1}{c}{ Factor } & \multicolumn{1}{c}{ Level } & $\begin{array}{c}\text { \% Survival } \\
\text { (SE) }\end{array}$ \\
\hline Physiographic & AP & $49(4)$ \\
Province & RV & $66(3)$ \\
\hline & Control & $33(5)$ \\
Management & Single Burn & $42(6)$ \\
Regime & DLC & $74(5)$ \\
& Shelterwood & $81(3)$ \\
\hline \multirow{2}{*}{ Aspect } & NE & $56(3)$ \\
\hline \multirow{2}{*}{ Fence } & SW & $60(3)$ \\
\hline Total & Unfenced & $53(3)$ \\
\hline
\end{tabular}


Survival was found to be a function of interacting factors GSF $(P=0.029)$. The interactions of Province $\times$ Regime $(P=0.0004)$, Province $\times$ Fence $(P=0.0063)$, Regime $\times$ Aspect $(P=0.0177)$, and Regime $\times$ Fence $(P=.0103)$ were all significant. The main effects of Management Regime $(P=0.0033)$ and Fence $(P=0.0063)$ we also found to be significant, but their examination precluded by the interaction effects (Table 5).

Simple pairwise comparisons among levels of the Province $\mathrm{x}$ Regime interaction revealed significantly greater survival on single burn sites in the Ridge and Valley when compared to those in the Appalachian Plateau (difference $=57$ percentage points, $P=0.0133$ ). No other statistical differences in survival were present between provinces within a given Regime (Table $6)$.

Table 5. Type III test of GSF and fixed effects on second year survival

\begin{tabular}{lcccc}
\hline \multicolumn{1}{c}{ Effect } & Num DF & Den DF & F Value & Pr $>$ F \\
\hline GSF & 1 & 141 & 5.37 & $\mathbf{0 . 0 2 1 9}$ \\
Province & 1 & 15.3 & 0.79 & 0.3886 \\
Management Regime & 3 & 12.8 & 7.76 & $\mathbf{0 . 0 0 3 3}$ \\
Aspect & 1 & 122 & 3.36 & 0.0693 \\
Fence & 1 & 122 & 7.73 & $\mathbf{0 . 0 0 6 3}$ \\
Province x Regime & 3 & 11.1 & 13.88 & $\mathbf{0 . 0 0 0 4}$ \\
Province x Fence & 1 & 121 & 7.75 & $\mathbf{0 . 0 0 6 3}$ \\
Regime x Aspect & 3 & 116 & 3.51 & $\mathbf{0 . 0 1 7 7}$ \\
Regime x Fence & 3 & 117 & 3.93 & $\mathbf{0 . 0 1 0 3}$ \\
Province x Regime x Aspect & 3 & 116 & 2.25 & 0.0865 \\
\hline
\end{tabular}


Table 6. Contrasts of mean percent survival between levels of Province x Fence, Management Regime $x$ Province, Management Regime x Fence, and Management Regime x Aspect

\begin{tabular}{|c|c|c|c|c|c|}
\hline \multicolumn{2}{|c|}{ Contrast } & Difference & DF & t Value & $\operatorname{Pr}>t$ \\
\hline \multicolumn{6}{|c|}{---------Province x Fence----------- } \\
\hline $\mathrm{AP}(\mathrm{F})$ & v. $\quad$ AP(UF) & 2 & 138 & 0 & $>0.999$ \\
\hline $\mathrm{RV}(\mathrm{F})$ & v. RV(UF) & 18 & 105 & 4.01 & 0.0006 \\
\hline $\mathrm{AP}(\mathrm{F})$ & v. $\mathrm{RV}(\mathrm{F})$ & 18 & 23.9 & -2.11 & 0.1565 \\
\hline $\mathrm{AP}(\mathrm{UF})$ & v. RV(UF) & 2 & 25.1 & 0.52 & 0.9533 \\
\hline \multicolumn{6}{|c|}{--------Management Regime x Province---------- } \\
\hline $\mathrm{C}(\mathrm{AP})$ & v. $\mathrm{C}(\mathrm{RV})$ & -33 & 10.1 & -2.68 & 0.2175 \\
\hline $\mathrm{SB}(\mathrm{AP})$ & v. $\quad \mathrm{SB}(\mathrm{RV})$ & -57 & 11 & -4.22 & 0.0133 \\
\hline DLC(AP) & v. $\quad \mathrm{DLC}(\mathrm{RV})$ & 35 & 11.1 & 2.65 & 0.0797 \\
\hline SHW(AP) & v. $\mathrm{SHW}(\mathrm{RV})$ & 4 & 17.8 & 0.39 & 0.6882 \\
\hline \multicolumn{6}{|c|}{-------Management Regime x Fence-------- } \\
\hline $\mathrm{C}(\mathrm{F})$ & v. C(UF) & 1 & 135 & -0.18 & $>0.999$ \\
\hline $\mathrm{SB}(\mathrm{F})$ & v. $\mathrm{SB}(\mathrm{UF})$ & 7 & 125 & 0.76 & 0.9947 \\
\hline $\mathrm{DLC}(\mathrm{F})$ & v. $\quad$ DLC(UF) & 29 & 142 & 4.16 & 0.0015 \\
\hline $\mathrm{SHW}(\mathrm{F})$ & v. SHW(UF) & 8 & 80.4 & 0.6 & 0.9988 \\
\hline \multicolumn{6}{|c|}{--------Management Regime x Aspect-------- } \\
\hline $\mathrm{C}(\mathrm{NE})$ & v. $\mathrm{C}(\mathrm{SW})$ & -2 & 137 & -3.37 & 0.0218 \\
\hline $\mathrm{SB}(\mathrm{NE})$ & v. $\mathrm{SB}(\mathrm{SW})$ & -9 & 127 & -1.07 & 0.9617 \\
\hline DLC(NE) & v. $\operatorname{DLC}(\mathrm{SW})$ & 4 & 141 & 0.24 & $>0.999$ \\
\hline SHW(NE) & v. $\mathrm{SHW}(\mathrm{SW})$ & 8 & 77.1 & 0.63 & 0.9983 \\
\hline
\end{tabular}

Comparing different management regimes within the Ridge and Valley province, no differences were found to be significant. However, within the Appalachian Plateau, while there was no difference in survival between plots on the on shelterwood sites (83\%) and on diameterlimit cut sites $(92 \%, P=0.9998)$,these management regimes showed statistically higher survival compared to single burn and control plots, each of which exhibited an average survival rate of 14\% (Table7). 
Table 7. Percent survival and standard errors ( ) among management regimes for Appalachian Plateau (AP) and Ridge and Valley (RV) physiographic provinces. Means within a column without the same letter are statistically different at the $P<0.05$ level.

\begin{tabular}{llc}
\hline \multicolumn{1}{c}{$\begin{array}{c}\text { Management } \\
\text { Regime }\end{array}$} & AP & RV \\
\hline Control & $14(6) \mathrm{a}$ & $47(6) \mathrm{a}$ \\
Single Burn & $14(5) \mathrm{a}$ & $71(6) \mathrm{a}$ \\
DLC & $92(3) \mathrm{b}$ & $57(8) \mathrm{a}$ \\
Shelterwood & $83(4) \mathrm{b}$ & $79(4) \mathrm{a}$ \\
\hline
\end{tabular}

Survival varied simultaneously by the Province and Fence factors. Fenced plots within the Ridge and Valley province showed statistically higher survival than unfenced (difference $=18$ percentage points, $P=0.0006)$. Differences between fenced and unfenced plots were not significant $(P=0.2175)$ within the Appalachian Plateau. There were no significant differences between provinces among fenced plots $(P=0.0797)$ or among unfenced plots $(P=0.6882)$ (Table $6)$.

Comparisons of survival rates between fenced versus unfenced plots within management regimes revealed a significant difference in survival present between diameter-limit cut sites. $89 \%$ survival on fenced plots was statistically greater than $60 \%$ survival on unfenced plots $(P=0.0015)$ (Table 6).

Among fenced plots, those on control sites showed a significantly lower survival rate (33\% survival) than those on shelterwood sites $(84 \%$ survival, $P<0.0369)$ and diameter-limit cut sites (89\% survival, $P<0.0001$ ) but was not statistically different from survival on single burn sites (46\% survival, $P=0.8744$ ). Survival rates for fenced plots on single burn sites were not significantly different from those on shelterwood sites $(P=0.3756)$ but did exhibit significantly 
lower survival than those on fenced diameter limit cut plots $(P=0.0017)$. Survival rates on these fenced diameter-limit cut plots were significantly higher than those on fenced control $(P<0.0001)$ and single burn plots $(P=0.002)$, but did not differ from those on fenced shelterwood plots $(P=0.72)($ Table 8$)$.

Table 8. Percent survival and standard errors ( ) among management regimes on fenced and unfenced plots. Means within a column without the same letter are statistically different at the $P<0.05$ level.

\begin{tabular}{lcc}
\hline \multicolumn{1}{c}{$\begin{array}{c}\text { Management } \\
\text { Regime }\end{array}$} & Fenced & Unfenced \\
\hline Control & $33(7) \mathrm{a}$ & $32(6) \mathrm{a}$ \\
Single Burn & $46(8) \mathrm{ab}$ & $39(8) \mathrm{ab}$ \\
Shelterwood & $84(3) \mathrm{bc}$ & $78(4) \mathrm{b}$ \\
DLC & $89(4) \mathrm{c}$ & $60(8) \mathrm{ab}$ \\
\hline
\end{tabular}

Among unfenced plots, survival on shelterwood sites (78\%) was statistically higher than that on control sites $(32 \%, P=0.0369)$. However, survival on unfenced shelterwood plots was not significantly different from that on single burns $(39 \%, P=0.2554)$. No statistical difference in survival was found between unfenced shelterwood plots and unfenced diameter limit cut plots $(P=0.9786)$. Survival on unfenced diameter-limit plots and unfenced control plots was not statistically different $(P=0.3279)$. Nor was the difference between unfenced diameter-limit cuts and single burn sites $(P=0.7415)$ (Table 8$)$.

Regarding the Regime $\mathrm{x}$ Aspect interaction, only on control sites was there a significant difference between northeast (23\%) and southwest aspects (43\%, $P=.0218)$ (Table 6). 
Significant differences among management regimes were present only on northeast aspects. A similar pattern was seen here as among management regimes within fenced plots. Survival was lowest on control sites (23\%) which differed significantly from shelterwood sites (difference $=62$ percentage points, $P=0.0006$ ) and diameter limit cut sites (difference $=53$ percentage points, $P=<0.0001)$. The 15 percentage point difference between the northeast aspect of single burn and control sites was not significant $(P=0.591)$. Plots on the northeast aspect of single burn sites did not show significantly different survival rates than those on control sites $(P=0.591)$ or shelterwood sites $(P=0.113)$. Survival rates on diameter-limit cut sites were 35 percentage points greater than those on single burn sites $(P=0.0251)$. No significant differences were found between any of the management regimes on southwest aspects (Table 9)

Table 9. Percent survival and standard errors ( ) among management regimes on northeast and southwest aspects. Means within a column without the same letter are statistically different at the $P<0.05$ level.

\begin{tabular}{lcc}
\hline \multicolumn{1}{c}{$\begin{array}{c}\text { Management } \\
\text { Regime }\end{array}$} & Northeast & Southwest \\
\hline Control & $23(5) \mathrm{a}$ & $43(7) \mathrm{a}$ \\
Single Burn & $38(7) \mathrm{ab}$ & $47(8) \mathrm{a}$ \\
Shelterwood & $85(3) \mathrm{bc}$ & $77(4) \mathrm{a}$ \\
DLC & $76(7) \mathrm{c}$ & $72(7) \mathrm{a}$ \\
\hline $\mathrm{I}$ & &
\end{tabular}

\section{Diameter Growth}

Following two growing seasons, mean total growth was $0.91 \mathrm{~mm}$. Unadjusted mean growth of each main factor level is presented in Table 10. 
Table 10. Two year diameter growth and standard error ( ) by main factors levels

\begin{tabular}{llc}
\hline \multicolumn{1}{c}{ Factor } & \multicolumn{1}{c}{ Level } & $\begin{array}{c}\text { Diameter } \\
\text { Growth (SE) }\end{array}$ \\
\hline $\begin{array}{l}\text { Physiographic } \\
\text { Province }\end{array}$ & AP & $1.16(0.19)$ \\
& Control & $0.77(0.10)$ \\
Management & Single Burn & $0.63(0.21)$ \\
Regime & DLC & $1.09(0.17)$ \\
& Shelterwood & $1.33(0.14)$ \\
\hline \multirow{2}{*}{ Aspect } & NE & $0.97(0.11)$ \\
& SE & $0.85(0.13)$ \\
Fence & Unfenced & $0.83(0.12)$ \\
& Fence & $0.98(0.11)$ \\
\hline Total & & $0.91(0.08)$ \\
\hline
\end{tabular}

Table 11. Type III test of GSF and fixed effects on two-year relative diameter growth

\begin{tabular}{lcccc}
\hline \multicolumn{1}{c}{ Effect } & $\begin{array}{c}\text { Num } \\
\text { DF }\end{array}$ & $\begin{array}{c}\text { Den } \\
\text { DF }\end{array}$ & F Value & Pr > F \\
\hline GSF & 1 & 135 & 5.45 & $\mathbf{0 . 0 2 1}$ \\
Province & 1 & 16.8 & 2.81 & 0.112 \\
Regime & 3 & 12.4 & 0.16 & 0.924 \\
Aspect & 1 & 155 & 0.38 & 0.539 \\
Fence & 1 & 161 & 0.17 & 0.681 \\
Province x Fence & 1 & 161 & 5.93 & $\mathbf{0 . 0 1 6}$ \\
Regime x Fence & 3 & 160 & 4.73 & $\mathbf{0 . 0 0 4}$ \\
Province x Regime x Fence & 6 & 25.4 & 1.64 & 0.177 \\
\hline
\end{tabular}

As with survival, diameter growth was found to be a function of interacting factors and GSF $(P=.0211)$. Significant interaction effects on diameter growth included Province $\mathrm{x}$ Fence $(P=0.016)$ and Regime $\mathrm{x}$ Fence $(P=0.0035)$ (Table 11). 
The difference in diameter growth between fenced Ridge and Valley plots and unfenced Ridge and Valley plots was significant, as fenced plots average $0.23 \mathrm{~mm}$ greater growth than unfenced $(P=0.031)$ (Table 12). No significant difference was present between fenced and unfenced plots in the Appalachian Plateau (difference $=0.11, P=0.6417$ ). Fenced plots in the Appalachian Plateau exhibited $0.29 \mathrm{~mm}$ greater growth than those in the Ridge and Valley, but this difference was not statistically significant $(P>0.9999)$. Among unfenced plots, those in the Appalachian Plateau grew significantly more in diameter than those in the Ridge and Valley (difference $=0.4 \mathrm{~mm}, P=0.0187)$.

Table 12: Diameter growth contrasts of levels within the significant interaction effects of Province $x$ Fence and Management Regime x Fence

\begin{tabular}{|c|c|c|c|c|c|}
\hline & Contrast & Difference & DF & t Value & $\operatorname{Pr}>\mathbf{t}$ \\
\hline \multicolumn{6}{|c|}{ 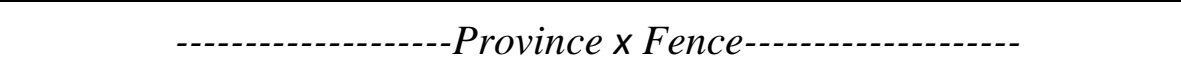 } \\
\hline $\mathrm{AP}(\mathrm{F})$ & v. $\mathrm{RV}(\mathrm{F})$ & 0.29 & 38.2 & 0.06 & $>0.999$ \\
\hline $\mathrm{AP}(\mathrm{UF})$ & v. $\mathrm{RV}(\mathrm{UF})$ & 0.4 & 25.5 & 2.95 & 0.019 \\
\hline $\mathrm{AP}(\mathrm{F})$ & v. $\mathrm{AP}(\mathrm{UF})$ & 0.11 & 160 & 1.18 & 0.642 \\
\hline $\mathrm{RV}(\mathrm{F})$ & v. RV(UF) & 0.22 & 162 & 2.78 & 0.031 \\
\hline \multicolumn{6}{|c|}{-----------Management Regime x Fence---------- } \\
\hline $\mathrm{C}(\mathrm{F})$ & v. $\mathrm{C}(\mathrm{UF})$ & -0.58 & 161 & -1.9 & 0.552 \\
\hline $\mathrm{SB}(\mathrm{F})$ & v. SB(UF) & 0.2 & 158 & 0.34 & $>0.999$ \\
\hline $\operatorname{DLC}(\mathrm{F})$ & v. DLC(UF) & 0.66 & 161 & 3.62 & 0.009 \\
\hline SHW(F) & v. SHW(UF) & 0.08 & 154 & 0.44 & $>0.999$ \\
\hline
\end{tabular}

Pairwise comparisons for Regime $x$ Fence interactions showed fenced diameter-limit cut plots to have statistically greater diameter growth than unfenced (difference $=0.66 \mathrm{~mm}$, $P=0.0091$ ). No difference existed between management regimes within fence levels (Table 12). 
Table 13: Diameter growth in millimeters and standard errors ( ) among management regimes on fenced and unfenced plots. Means within a column without the same letter are statistically different at the $P<0.05$ level.

\begin{tabular}{lcc}
\multicolumn{1}{c}{$\begin{array}{c}\text { Management } \\
\text { Regime }\end{array}$} & Fenced & Unfenced \\
\hline Control & $0.03(0.26) \mathrm{a}$ & $0.56(0.32) \mathrm{a}$ \\
Single Burn & $0.74(0.18) \mathrm{a}$ & $0.53(0.27) \mathrm{a}$ \\
DLC & $1.37(0.22) \mathrm{a}$ & $0.71(.25) \mathrm{a}$ \\
Shelterwood & $1.37(0.2) \mathrm{a}$ & $1.29(0.21) \mathrm{a}$ \\
\hline
\end{tabular}

\section{Height Growth}

Total average height growth over two growing seasons was $13.49 \mathrm{~cm}$. Unadjusted mean height growth of each main factor level is presented in Table 14.

Table 14. Unadjusted two year height growth and standard error ( ) by main factors levels

\begin{tabular}{llc}
\hline \multicolumn{1}{c}{ Factor } & \multicolumn{1}{c}{ Level } & $\begin{array}{c}\text { Height } \\
\text { Growth (SE) }\end{array}$ \\
\hline $\begin{array}{l}\text { Physiographic } \\
\text { Province }\end{array}$ & AP & $19.29(1.19)$ \\
& RV & $10.36(1.1)$ \\
\hline Management & Control & $7.22(2.75)$ \\
Regime & Single Burn & $15.26(1.29)$ \\
& DLC & $14.47(1.9)$ \\
\hline Aspect & Shelterwood & $17.71(1.05)$ \\
\hline \multirow{2}{*}{ Fence } & NE & $13.50(1.3)$ \\
& SE & $13.47(1.2)$ \\
\hline Total & Unfenced & $12.39(1.31)$ \\
\hline
\end{tabular}


Table 15. Type III test GSF and fixed effects on two-year relative height growth ${ }^{\mathrm{a}}$

\begin{tabular}{lcccc}
\hline \multicolumn{1}{c}{ Effect } & Num DF & Den DF & F Value & Pr > F \\
\hline GSF & 1 & 30.9 & 1.21 & 0.2796 \\
Province & 1 & 22.6 & 4.37 & $\mathbf{0 . 0 4 8}$ \\
Regime & 3 & 10.1 & 2.53 & 0.1159 \\
Aspect & 1 & 126 & 0.15 & 0.6954 \\
Fence & 1 & 107 & 5.98 & $\mathbf{0 . 0 1 6 1}$ \\
Province x Aspect & 1 & 112 & 3.82 & 0.0532 \\
Regime x Aspect & 3 & 118 & 3.06 & $\mathbf{0 . 0 3 0 8}$ \\
\hline
\end{tabular}

Tests of the main effects and interactions revealed Province $(P=0.048)$ and Fence $(P=0.0161)$ as significant Table 15. Height growth on Appalachian Plateau sites was greater that than on Ridge and Valley sites (difference $=7.68 \mathrm{~cm}$ ). Fenced plots exhibited greater growth than unfenced $($ difference $=2.12 \mathrm{~cm})($ Table 16).

The Regime $x$ Aspect interaction also appeared statistically significant $(P=0.0308)$.

However, tests of comparisons using the more conservative Tukey adjusted $P$-value produced no significant differences either between aspects within a given management regime (Table 16) or among management regimes on a given aspect (Table 17).

Table 16. Height growth contrasts of main effects and levels within the significant interaction effects of Province x Fence and Management Regime x Fence

\begin{tabular}{|c|c|c|c|c|c|}
\hline \multicolumn{2}{|c|}{ Contrast } & Difference & DF & t Value & $\operatorname{Pr}>t$ \\
\hline \multicolumn{6}{|c|}{ 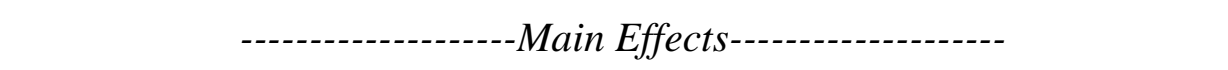 } \\
\hline AP & v. $\mathrm{RV}$ & 7.68 & 22.6 & 2.09 & 0.048 \\
\hline $\mathrm{F}$ & v. UF & 2.12 & 107 & 2.45 & 0.0161 \\
\hline \multicolumn{6}{|c|}{----------Management Regime x Aspect---------- } \\
\hline $\mathrm{C}(\mathrm{NE})$ & v. $\mathrm{C}(\mathrm{SW})$ & -7.02 & 153 & -1.09 & 0.9586 \\
\hline $\mathrm{SB}(\mathrm{NE})$ & v. $\mathrm{SB}(\mathrm{SW})$ & -1.64 & 129 & -1.32 & 0.8903 \\
\hline $\mathrm{DLC}(\mathrm{NE})$ & v. $\operatorname{DLC}(\mathrm{SW})$ & 5.90 & 100 & 2.38 & 0.2592 \\
\hline SHW(NE) & v. SHW(SW) & 0.55 & 75.3 & -0.63 & 0.9984 \\
\hline
\end{tabular}


Table 17. Height growth in millimeters and standard errors ( ) among management regimes on northeast and southwest plots. Means within a column without the same letter are statistically different at the $P<0.05$ level.

\begin{tabular}{|c|c|c|}
\hline \multirow[b]{2}{*}{$\begin{array}{c}\text { Management } \\
\text { Regime }\end{array}$} & \multicolumn{2}{|c|}{ Aspect } \\
\hline & Northeast & Southwest \\
\hline Control & $3.14(4.27) \mathrm{a}$ & $10.16(3.54) \mathrm{a}$ \\
\hline Single Burn & $14.39(1.72) \mathrm{a}$ & $16.03(1.93) \mathrm{a}$ \\
\hline DLC & $17.43(2.58) \mathrm{a}$ & $11.52(2.78) \mathrm{a}$ \\
\hline Shelterwood & $17.99(1.46) \mathrm{a}$ & $17.44(1.54) \mathrm{a}$ \\
\hline
\end{tabular}

\section{Light, Performance, and Forest Structure}

Physiographic province, managment regime, and aspect were fixed effects which implicitly incorporate light levels. This is particularly true of management regimes. As discussed previously, silvicultural prescriptions which aim to promote oak regeneration are primarily concerned with creating favorable light conditions through the manipulation of stand structure. As planted seedlings are not responding to designations such as shelterwood, but to environmental conditions with which they are associated, the relationship between GSF, seedling performance, and forest structure is examined more closely.

\section{Light and Performance}

Simple linear regression showed a significant positive association between GSF $\left(R^{2}=0.0691, P=.0001\right)$ and diameter growth (Table 18, Figure 4). No association was present between height growth and GSF ( $P=0.6763)$ (Table 18, Figure 6). Simple logistical regression of stocking on GSF was significant $(P<0.0001)$, with the probability of a given plot being stocked increasing with increases in GSF. The odds ratio estimate shows that with a one unit change in 
arcsine square root transformed GSF, the odds of a given plot being stocked is expected to increase by $11 \%($ Odds ratio $=1.107, P<.0001)$. Plotted probabilities for stocking show a steady increase with increasing GSF before beginning to plateau at approximately 15-20\% (Figure 6).

Table 18. Regressions of GSF on relative diameter growth and relative height growth

\begin{tabular}{|c|c|c|c|c|}
\hline Variable & $\begin{array}{c}\text { Parameter } \\
\text { Estimate }\end{array}$ & $\begin{array}{l}\text { Standard } \\
\text { Error }\end{array}$ & t Value & $\operatorname{Pr}>|\mathbf{t}|$ \\
\hline \multicolumn{5}{|c|}{ Relative Diameter Growth $(R$-Squared $=0.0691)$} \\
\hline Intercept & 0.75968 & 0.01 & 53.12 & $<.0001$ \\
\hline $\mathrm{GSF}^{\mathrm{a}}$ & 0.00102 & 0.03 & 3.89 & 0.0001 \\
\hline \multicolumn{5}{|c|}{ Relative Height Growth (R-squared=0.0009) } \\
\hline Intercept & 0.37771 & 0.05 & 7.15 & $<.0001$ \\
\hline GSFa & -0.00040 & 0.10 & -0.42 & 0.6763 \\
\hline
\end{tabular}

${ }^{\mathrm{a}}$ Analysis was run using arcsine-square root transformed GFS

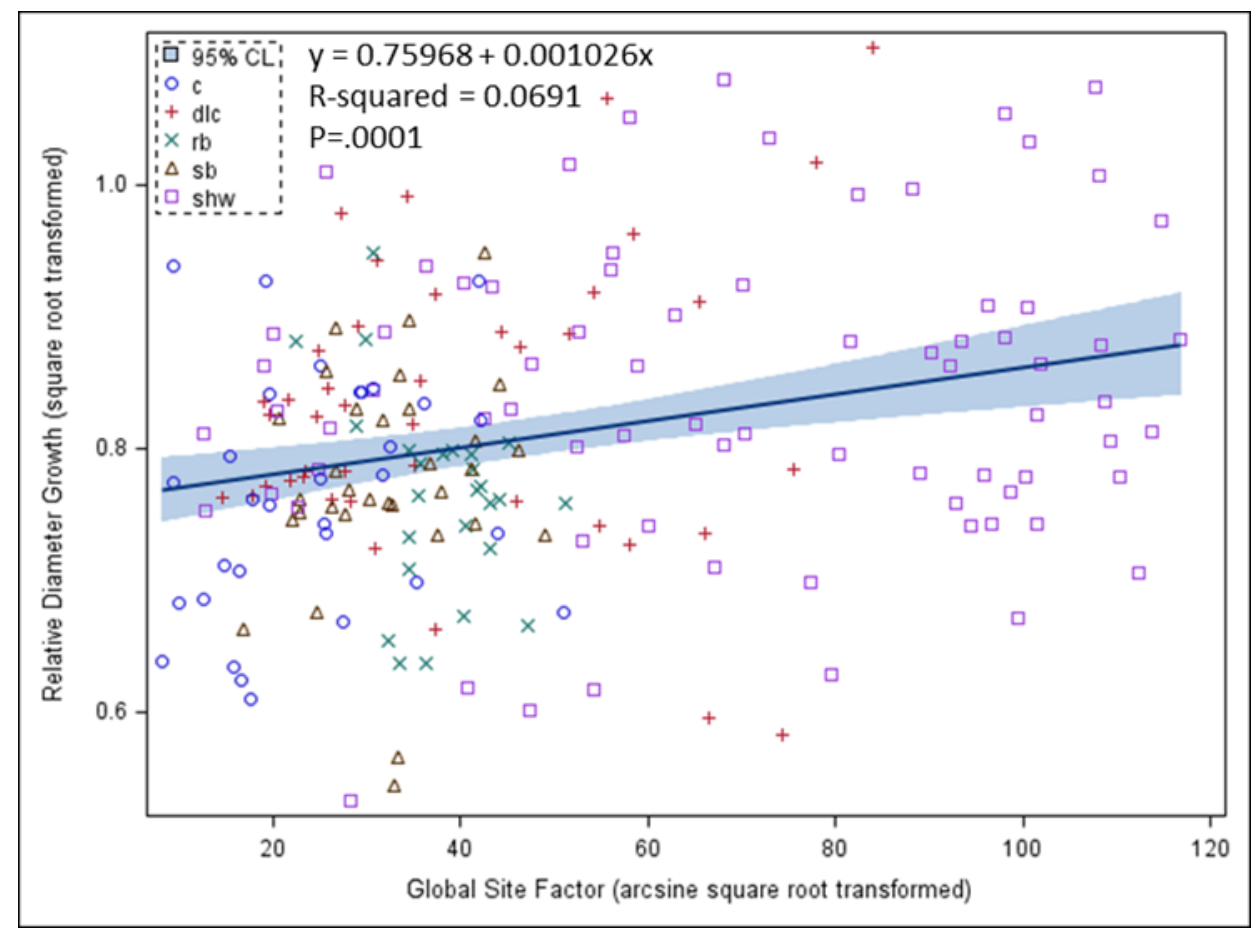

Figure 4. Regression of relative diameter growth on arcsine square root transformed GSF 


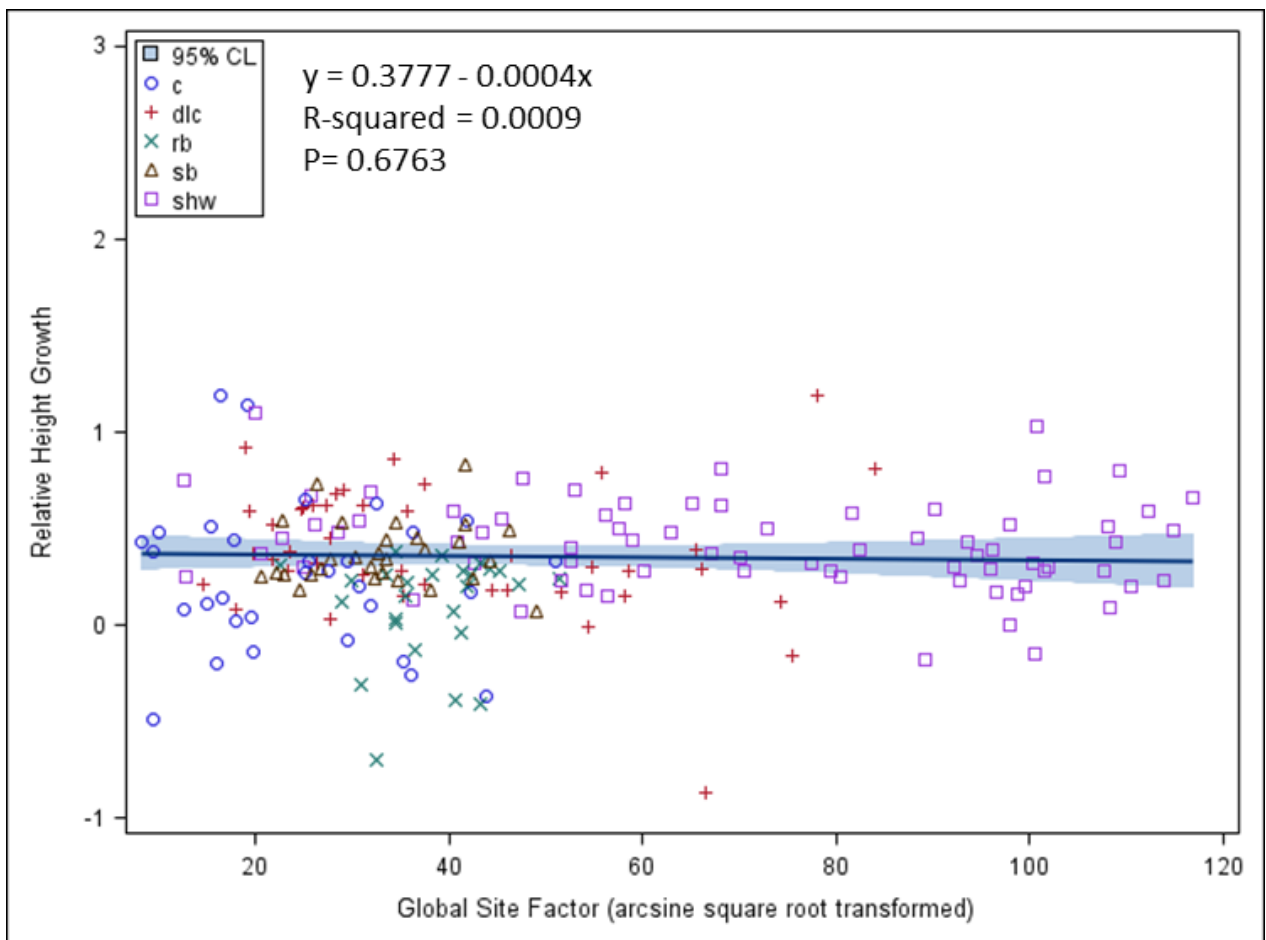

Figure 5. Regression of relative diameter growth on arcsine square root transformed GSF

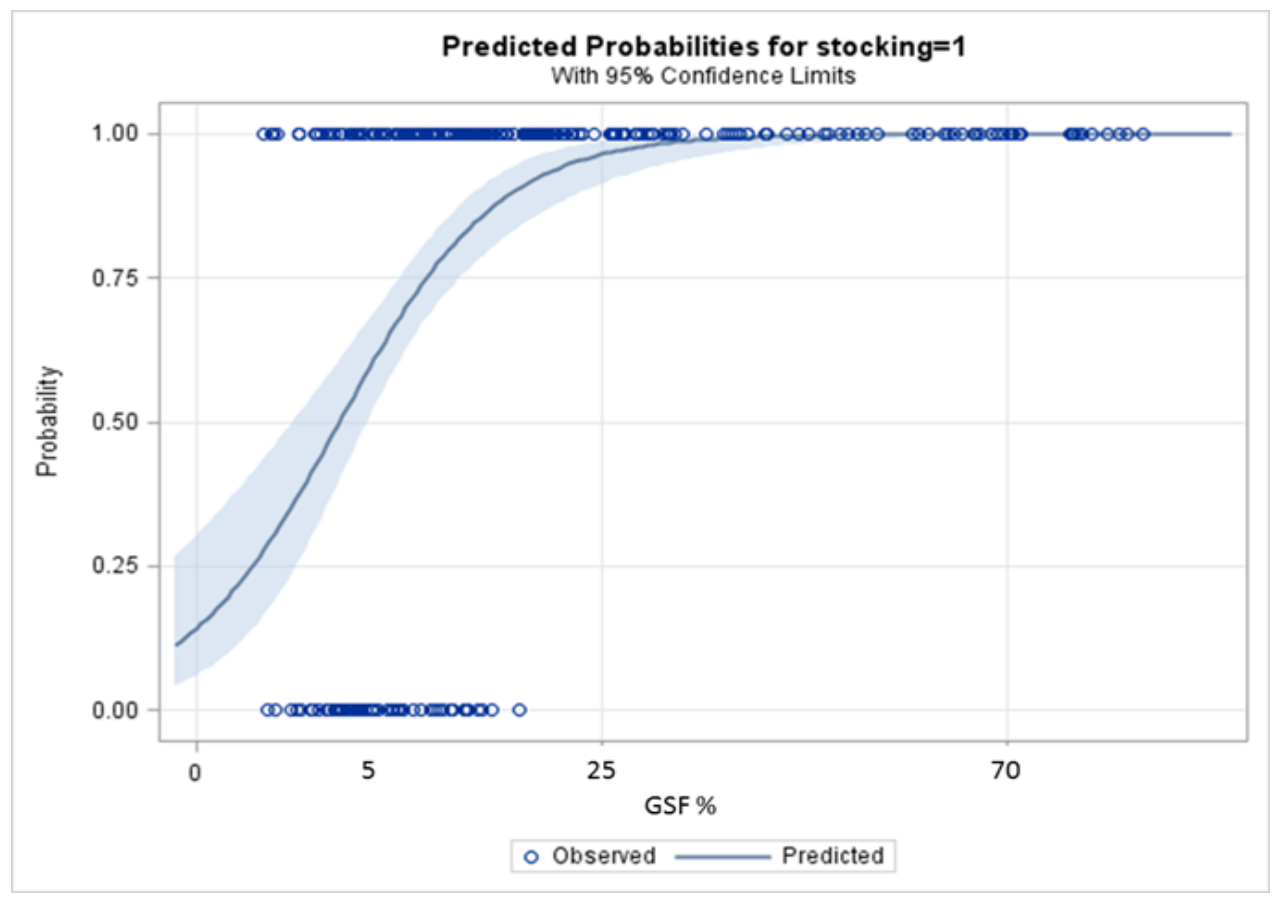

Figure 6. Plotted probability of stocking with increased GSF. While arcsine square root transformed was used in logistic regression, untransformed values are presented on the $\mathrm{x}$-axis. 


\section{Light and Stand Structure}

In general, light increased with decreasing basal area. Average GSF was greatest under shelterwood sites (44\%) and lowest on control sites (3\%). Light levels showed a pattern associated with province. Ridge and Valley sites had greater light than Appalachian Plateau sites for any given management regime (Table 19, Figure 7).

Table 19. Global site factor and standard error ( ) by main factors levels

\begin{tabular}{llc}
\hline \multicolumn{1}{c}{ Factor } & \multicolumn{1}{c}{ Level } & GSF (SE) \\
\hline Physiographic & AP & $2.8(0.3)$ \\
Province & RV & $6.5(0.5)$ \\
\hline \multirow{4}{*}{ Management } & Control & $4.4(0.3)$ \\
Regime & Repeat Burn & $11.0(1.7)$ \\
& Single Burn & $19.5(2.2)$ \\
& DLC & $8.3(1.0)$ \\
& Shelterwood & $12.1(1.0)$ \\
\hline \multirow{2}{*}{ Aspect } & NE & $14.1(0.8)$ \\
& SW & $21.4(3.5)$ \\
\hline \multirow{2}{*}{ Fence } & Unfenced & $65.2(2.3)$ \\
& Fence & $2.8(0.3)$ \\
\hline Total & & $6.5(0.5)$ \\
\hline
\end{tabular}

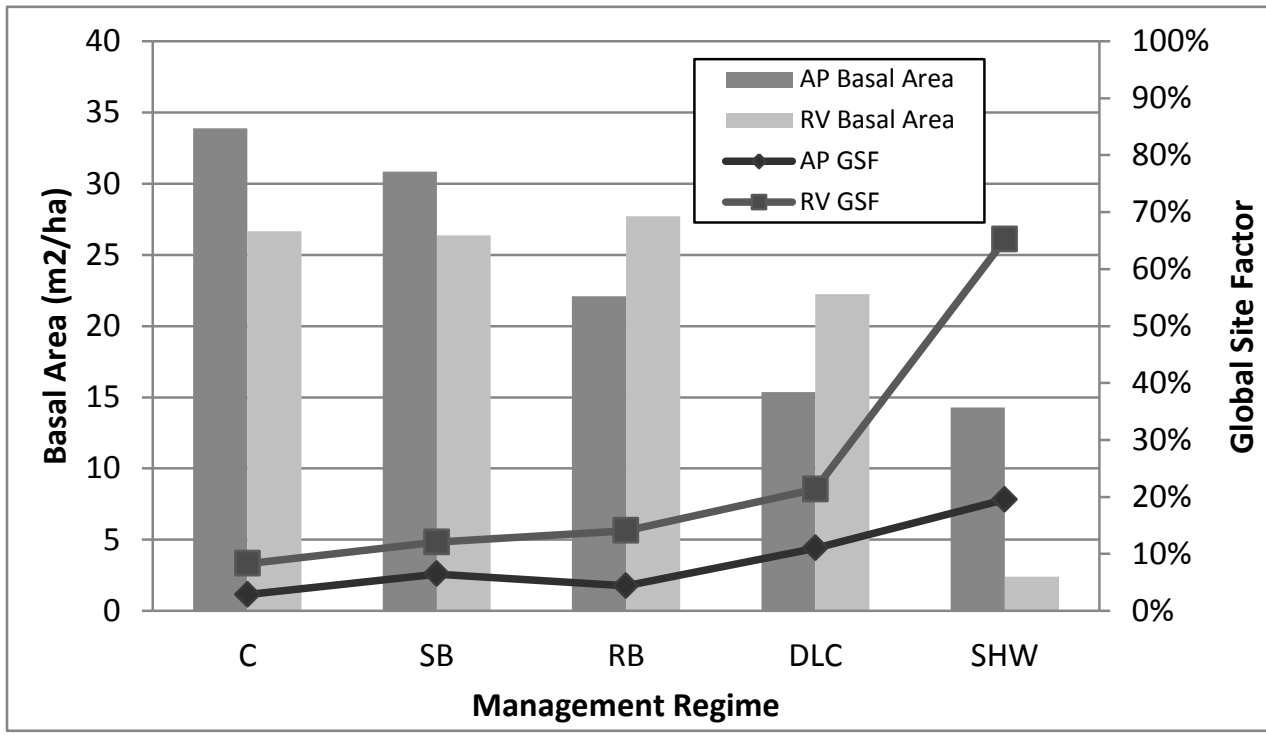

Figure 7. Basal area and global site factor by management regime and province. Note the consistently greater light levels in the Ridge and Valley province across all managements 
Multiple linear regression was used to examine the relationship between stand structure and light. A model including basal area, sapling density, interfering understory vegetation, and total herbaceous cover was run and reduced with the stepwise selection routine. Using AIC as the selection criteria and a minimum $P$-value of 0.15 for inclusion, a model consisting of basal area and sapling density was determined to be the "best" in explaining variability in GSF.

$$
Y=\beta_{0}+\beta_{\mathrm{BA}} \mathrm{X}_{\mathrm{BA}}+\beta_{\mathrm{SD}} \mathrm{X}_{\mathrm{SD}+\varepsilon}
$$

Where $Y=$ GSF

$\beta_{\mathrm{BA}}=$ Slope associated with basal area

$\mathrm{X}_{\mathrm{BA}}=$ Basal Area $\left(\mathrm{m}^{2} / \mathrm{ha}\right)$

$\beta_{\mathrm{SD}} \mathrm{X}=$ Slope associated with sapling density

$\mathrm{X}_{\mathrm{SD}}=\log ($ Sapling density (stems/ha) +1$)$

A significant negative relationship was found between GSF and basal area $\left(\beta_{\mathrm{BA}}=-\right.$ $0.01974, P<0.0001)$ and sapling density $\left(\beta_{\mathrm{SD}}=-0.10702, P<.0001\right) . R$-squared for the model was 0.678. Standardized estimates were -0.75 and -0.29 for basal area and sapling density, respectively, indicating basal area to be more influential on GSF (Table 20).

When examining this model within each province, vegetation structure was less effective in explaining variability in GSF within the Appalachian Plateau. While a negative relationship with basal $\left(\beta_{\mathrm{BA}}=-0.90, P<0.0001\right)$ and sapling density $\left(\beta_{\mathrm{SD}}=-2.12, P<0.0001\right)$ remained significant, the model explained only $37 \%$ of the variation in GSF (Table 20). Standardized estimates showed basal area (-0.54) to be less influential in the Appalachian Plateau than on all plots combined. The influence of sapling density $(-0.29)$ remained relatively constant. 
Table 20. Estimates and standardized estimates of regression of GSF on basal area and sapling density

\begin{tabular}{|c|c|c|c|c|c|}
\hline Variable & $\begin{array}{c}\text { Parameter } \\
\text { Estimate(SE) }\end{array}$ & $\begin{array}{c}\text { Standard } \\
\text { Error }\end{array}$ & t Value & $\operatorname{Pr}>|t|$ & $\begin{array}{c}\text { Standardized } \\
\text { Estimate }\end{array}$ \\
\hline \multicolumn{6}{|c|}{ - } \\
\hline Intercept & $90.92(2.3)$ & 2.30 & 39.53 & $<.0001$ & 0.00 \\
\hline Basal Area & $-1.93(0.09)$ & 0.09 & -21.39 & $<.0001$ & -0.75 \\
\hline Sapling Density & $-2.83(0.35)$ & 0.35 & -8.15 & $<.0001$ & -0.29 \\
\hline \multicolumn{6}{|c|}{--------Appalachian Plateau(adj. $\left.R^{2}=0.3712\right)---1$} \\
\hline Intercept & $61.59(4.04)$ & 4.04 & 15.26 & $<.0001$ & 0.00 \\
\hline Basal Area & $-0.90(0.12)$ & 0.12 & -7.44 & $<.0001$ & -0.54 \\
\hline Sapling Density & $-2.12(0.50)$ & 0.50 & -4.26 & $<.0001$ & -0.31 \\
\hline \multicolumn{6}{|c|}{ 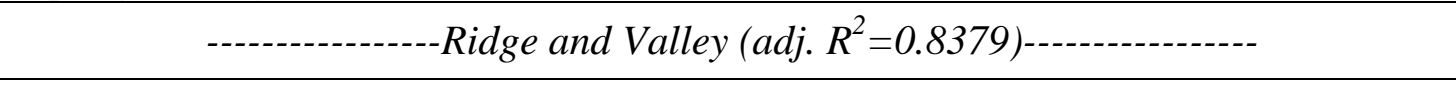 } \\
\hline Intercept & $93.99(2.50)$ & 2.50 & 37.67 & $<.0001$ & 0.00 \\
\hline Basal Area & $-2.40(0.09)$ & 0.09 & -26.73 & $<.0001$ & -0.90 \\
\hline Sapling Density & $4.02(1.16)$ & 1.16 & 3.47 & 0.0007 & 0.12 \\
\hline
\end{tabular}

Both basal area $\left(\beta_{\mathrm{BA}}=-2.40, P<00001\right)$ and sapling density $\left(\beta_{\mathrm{SD}}=4.02, P=0.0007\right)$

remained significant within the Ridge and Valley Province as well. However, sapling density was positively associated with GSF here, indicating a response in the sapling layer to increases in light levels rather than a shading effect. Basal area exerted a stronger influence on GSF than in the Appalachian Plateau or overall, with a standardized estimate of -0.9 relative to that of 0.12 for sapling density. The entire model was a stronger fit in the Ridge and Valley, explaining almost $84 \%$ of variation in light (adjusted R-square $=0.838$ ). 


\section{DISCUSSION}

As the regeneration of oak, particularly on high productivity sites, remains problematic, continued research into methods to promote the establishment and growth of advanced reproduction is necessary. Despite the wealth of research on the topic, ambiguity still remains and consistently successful and widely applicable prescriptions are elusive. One source of this ambiguity in the current literature is the wide geographic range of oaks, including the subject of study, northern red oak. High variability from site to site and region to region within this range makes the direct transfer and application of research difficult (Dey et al. 2009, Dey et al. 2007, Dey et al. 2010, Johnson et al. 2002, Loftis 2004). A greater number of studies which enable the direct comparison of the effectiveness of prescriptions across existing environmental gradients are needed. This study seeks to address this need and contribute to the current body of knowledge regarding underplantings and oak regeneration in general. Present knowledge on the subject was reinforced, as this research corroborates findings on the feasibility of underplanting, the influence of management and physiographic province in determining its suitability and seedling vigor, the more direct relationship between seedling performance and variable light conditions, and the potential influence of deer herbivory.

The difference in light levels between provinces within management regimes highlights the importance of understanding the mid and understory communities and their influence on light conditions. More specifically, the significance of the sapling layer in affecting Appalachian Plateau light levels revealed low shade to be an important factor in this province, and one which merits due consideration in the application of silvicultural prescriptions. Brose (2011) found similar results supporting the importance of early low shade removal in north-central Pennsylvania, also within the Appalachian Plateau. Here, a preparatory cut resulted in an 
increase from 4\% PAR to14\% PAR in cut stands. Lorimer et al. (1994) found removal of tall understory stems in a southwestern Wisconsin stand to increase survival of planted northern red oaks as well as natural oak reproduction. Brose (2011) and other field studies report that high mortality occurs at or near 5\% full sunlight, while light levels greater than $10 \%$ produce significant increases in survival and growth (Loftis 1990, Lorimer et al. 1994, Miller et al. 2004). Studies of oak seedling growth and physiology in controlled environments support this, identifying $\sim 5 \%$ full sunlight as the minimum level to maintain existing tissues and observing increases in photosynthesis and growth up to 20-30\% full sunlight, after which the benefits of greater light begins to plateau (Gottschalk 1994; Johnson et al. 2002; Rebbeck et al. 2011, Rebbeck et al. 2012). This general consensus is consistent with findings here, as GSF levels near and below 5\% resulted in survival below 15\% within the Appalachian Plateau. However, in both regimes, increase in light levels to $\sim 10 \%$ on DLC sites and $\sim 20 \%$ on shelterwood sites was sufficient to produce survival greater than $80 \%$.

That survival was greater on single burn sites in the Ridge and Valley province is consistent with findings elsewhere that fires are more intense and effective in altering stand structure and promoting oak regeneration on drier sites (Brose et al. 2006, Elliot et al. 1999). In contrast, the introduction (or reintroduction) of fire on higher quality Appalachian Plateau sites undergoing the process of "mesophication" outlined by Nowaki and Abrams (2008) is challenging and not generally successful with a single burn (Brose et al. 2001, Brose et al. 2006, Elliot et al. 1999, Hutchinson et al. 2005, Iverson et al. 2008, Signell et al. 2005). That light levels and survival rates on burns in the Appalachian Plateau most closely resembled those on control sites reinforces this conclusion, while light levels on single burns in the Ridge and Valley averaged $12 \%$ and survival was high $(71 \%)$. 
Aspect was the other environmental gradient of interest to this study. Aspect was not a significant effect in itself. As with the more mesic Appalachian Plateau province, differences in survival were more distinct on northeast aspects, where single burn and control sites showed lower survival than DLC and shelterwood. Again, differences were muted on drier sites, as only control and shelterwood sites showed statistically different survival rates on southwest aspects.

In general, average growth was relatively low. That no statistical differences in growth were present between management regimes was surprising. However, average diameter growth was ranked consistently with that which would be expected given the average light levels under management regimes. High site-to-site variability and the loss of growth measurements due to mortality may have limited our ability to make statistical inferences. In addition, the short duration of the study may not have provided enough time for responses to treatments to become fully differentiated. However, without associating undue meaning with non-significant results, this progression is ecologically intuitive, consistent with survival results, and lends support to the finding that plantings did respond positively to increased light and partial overstory removal.

Fencing appeared as a significant factor influencing diameter and height growth as well as survival. Exclusion of deer from plots resulted in significantly greater height growth. In regard to diameter growth and survival, the interaction of fence and province suggests that deer pressure is greater in the Ridge and Valley province. Estimates from the 2012 hunting season, communication with resource managers, and previous publications support the implication that density around sites in the Ridge and Valley is indeed greater at those in the Appalachian Plateau, averaging $7-7.5 / \mathrm{km}^{2}$ in the former and $6-6.5 / \mathrm{km}^{2}$ in the latter (Apsley and McCarthy 2004, WV.gov 2013, Kocka 2013). While this difference is not extreme, studies have shown $7.9 / \mathrm{km}^{2}$ to be the threshold at which herbivory initiates a shift in species composition and 
negatively affects regeneration (deCalesta 1992, Tilghman 1989). Estimates for the Ridge and Valley approach this density.

Importantly, regional estimates may be of limited use as densities can vary greatly from site to site. Furthermore, actual deer densities and browse pressure are difficult to quantify and dynamic across time and space. This is particularly true with respect to private land which typically lacks conscious deer management objectives and may exclude hunting. Furthermore, browse pressure is not simply a function of density but also the appeal and "apparency" of plants in relation to the surrounding species and landscape (Seagle and Liang 1997). Diameter-limit cuts create visible disturbances on the landscape and produce browse attractive to deer. In addition, the Grimes' and Clover Lick sites were located on larger properties constituted by multiple stands which are harvested intermittently. This landscape level disturbance regime may produce browse to support larger deer populations relative to more contiguous mature forests. Overall, in the absence of site specific estimations, improved performance of seedlings within fenced plots and county level estimations suggest that deer pressure is greater in the Ridge and Valley and ambient densities are sufficient to negatively impact the growth and survival of underplantings. 


\section{CONCLUSION and IMPLICATIONS}

Where deer herbivory was excluded through fencing, higher light levels partially associated with a less dense sapling layer in the Ridge and Valley resulted in sites which were more conducive to oak regeneration. The higher survival on single burn sites and lack of statistical difference among management regimes within the province suggests underplantings are better able to persist and develop without overstory manipulation and with less intensive management here. Results of this study suggest greater reduction in basal area among Ridge and Valley shelterwood sites exceeded those necessary to promote higher survival and vigor in underplantings. While economic considerations and specific management objectives may encourage a heavy seed cut as seen on these sites, it appears lighter harvests are sufficient from a silvicultural standpoint and may be more desirable. This may be the case on sites where aesthetics or the expansion of invasive and other undesirable pioneer species are of concern. Many of these sites could reasonably be considered capable of accumulating sufficient oak advanced reproduction through a natural regeneration system, making underplanting unnecessary (Loftis 1994, Johnson et al. 2002). However, should management objectives demand greater oak advanced reproduction than that which developed naturally, these short-term findings suggest that incorporation of underplanting into management prescriptions may be ecologically/silviculturally feasible, but requires more study. Such a situation is conceivable in restoring a component of oak in a stand where repeated selection cuts, or diameter limit cutting have resulted not only in the absence of oak advanced reproduction, but also a reduction in the number and quality of dominant and codominant oaks acting as seed sources (Paquette et al. 2006). 
In contrast, high sapling density and low shade within the Appalachian Plateau was associated with an overall decrease in light across all management regimes. The more intense disturbance of shelterwood and diameter limit cuts, however, resulted in seedling survival comparable to that in the Ridge and Valley as well as greater height growth indicative of the generally superior site quality. These results suggest that the potential for supplementing natural reproduction with underplanting is present within the Appalachian Plateau province, but application is more restricted than in the Ridge and Valley. Even on single burn sites, where mean sapling density was lower than in other management regimes, it was still greater than within the Ridge and Valley, and stand structure was not sufficiently altered to create conditions favorable to oak seedling growth and development. Also, though survival was high under diameter limit cuts, light levels did not reach the $20 \%$ ideal as in the Ridge and Valley.

Regarding those seedlings which did survive, the short duration of the study and absence of data on the current status of competing vegetation relegates any speculation on the future success of these plantings to just that, speculation. However, growth and high survival rates under diameter limit cuts and shelterwood harvests suggests that the use of enrichment plantings to supplement natural regeneration have potential when used in conjunction with management practices which sufficiently increase available light. That this was achieved under shelterwood harvests was expected, as this method is a regeneration harvest designed to promote intermediate tolerance species such as oaks. The associated environmental conditions and seedling response to diameter-limit cutting was less certain, as it is not a regeneration harvest, but rather highly variable and commercially guided. It is both common in the region and frequently implicated in the replacement of oaks by shade tolerant species, therefore, the possibility of such harvests to facilitate the establishment and growth of under plantings is of interest. As the practice 
continues, the ability to supplement stands denuded of both mature, acorn producing oaks and advanced reproduction is desirable. High average survival on these sites merit cautious optimism regarding the feasibility of underplanting on diameter limit cuts, it is worth reiterating that this study is of insufficient length to suggest early growth and survival equates to long term success. This is especially true as, unlike under the shelterwood method, there is no expectation that underplantings in diameter-limit cuts will be released through a future overstory removal. Furthermore, great variability among diameter limit cuts was present within this study, ranging from sites with shelterwood-like conditions to those most comparable to controls regarding light and survival.

Though higher survival with less intensive management would appear an endorsement for underplanting in the Ridge and Valley, it represents a trade-off. These sites are of lower productivity and would be expected to produce slower growing, lower quality trees. As mentioned above, it is also probable that these sites could be more easily managed to accumulate natural oak advanced reproduction, making underplanting superfluous. Therefore, though survival of underplantings may be more assured in the Ridge and Valley than on the higher productivity sites in the Appalachian Plateau, in most situations it is questionable whether, planting is necessary or merits the investment on such sites. In contrast, sites which require concerted effort and management to achieve high planting survival are also the most problematic to naturally regenerate oaks, and are therefore logical candidates for underplanting. That being said, without complete knowledge of current and future competition in relation to plantings on the Appalachian Plateau, a great deal of caution must be exercised when speculating on the future success of even the most vigorous seedlings after only two seasons of growth. 
For this reason, long term studies are necessary to truly gauge the success of underplantings. This research helps to refine the understanding of the nature of interactions between prescriptions and existing environmental gradients with an experimental design which facilitates direct comparison. It also provides a closer examination of the relationship between forest structure and light, the manipulation of which is often the objective of a given prescription. Finally, this study provides insight into the potential suitability of incorporating underplantings into what are typically natural regeneration based silvicultural systems in the region. However, strong conclusions on the viability of plantings are restricted, and further research into its use where natural advanced reproduction in inadequate is merited. The high survival under diameter limit cuts and shelterwood harvests is encouraging, but studies featuring a long-term competition based approach in assessing dominance probabilities would enhance the ability to draw practical conclusions from growth and survival data. Spetich et al. (2002) employed such an approach, examining planting success under shelterwoods in the Boston Mountains of Arkansas. Integrating competition, site quality, and seedling stock, the authors were able to provide useful planting guidelines based on the probablility of a given planting attaining co-dominant status. The need for comparable studies is only increasing as prescriptions ensuring successful regeneration of red oak, particularly on high quality sites, remain elusive. 


\section{WORKS CITED}

Abrams, M.D. 1998. The Red Maple Paradox. BioScience 48: 355-364.

Abrams, M.D. and G.J. Nowacki. 1992. Historical Variation in Fire, Oak Recruitment, and PostLogging Accelerated Succession inCentral Pennsylvania. Bulletin of the Torrey Botanical Club. 119: 19-28.

Adams A.S.; Rieske L.K. 2001. Herbivory and Fire Influence White Oak (Quercus alba L.) Seedling Vigor. Forest Science. 47:331-337.

Apsley, David K.; McCarthy, Brian C. 2004. White-tailed deer herbivory on forest regeneration following fire and thinning treatments in southern Ohio mixed oak forests. P.461-471 in Proceedings, 14th Central Hardwood Forest Conference, Wooster, OH. Yaussy, D.A., Hix, D. M., Long, R. P., and C.P. Goebel (eds.). US Forest Service Gen. Tech. Rep. NE316. 539 p.

Baker, F.S. 1949. A revised tolerance table. Journal of forestry. 47:179-181.

Blankenship, B.A. and M.A. Arthur. 2006. Stand Structure Over 9 Years in Burned and FireExcluded Oak Stands on the Cumberland Plateau, Kentucky. Forest Ecology and Management. 225:134-145.

Brose, P. H. 2011a. A comparison of the effects of different shelterwood harvest methods on the survival and growth of acorn-origin oak seedlings. Canadian Journal of Forest Research. 41: 2359-2374.

Brose, P.H. 2011b. Fate of the 2001 acorn crop at Clear Creek State Forest Pennsylvania. P. 253261 in Proceedings of the 17th central hardwood forest conference, Lexington, $K Y$. Fei, S., Lhotka, J.M., Stringer, J.W. Gottschalk, K.W., and G.W. Miller (eds.). US Forest Service Gen. Tech. Rep. NRS-P-78. 678 p.

Brose P., Schuler T., VanLear D. and J. Berst. 2001. Bringing fire back: The changing regimes of the Appalachian mixed-oak forests. Journal of Forestry 99:30-35.

Brose, P. H., Schuler, T. M., and J.S. Ward. 2006. Responses of oak and other hardwood regeneration to prescribed fire: What we know as of 2005. P123-145 in Fire in eastern oak forests conference: delivering science to land managers, Proceedings of a Conference. US Forest Service Gen. Tech. Rep. NRS-P-1.

Brose, P.H. and D.H. Van Lear. 2011. Responses of hardwood advance regeneration to seasonal prescribed fires in oak-dominated shelterwood stands. Canadian Journal of Forest Resources. 28:331-339. 
Carvell, K.L. and E.H. Tryon. 1961. The effect of environmental factors on the abundance of oak regeneration beneath mature oak stands. Forest Science. 7:98-105.

Castleberry, S. B., Ford, W. M., Miller, K.V. and W.P. Smith. 1999. White-Tailed Deer Browse Preferences in a Southern Bottomland Hardwood Forest. Southern Journal of Applied Forestry. 23:78-82.

Crow, T.R. 1988. Reproductive Mode and Mechanisms for Self-Replacement of Northern Red Oak (Quercus rubra) - A Review. Forest Science 34:19-40.

Crow, T.R. 1992. Population Dynamics and Growth Patterns for a cohort of northern red oak (Quercus rubra) seedlings. Oecologia 91, 192-200.

DeBord, W.W., Buckley, D.S., Sharik, T.L. Hartmans, J.P., and J.G. Henning. 2011. Effects of two prescribed fires on red maple regeneration across four levels of canopy cover. P. 665668 in Proceedings, 17th central hardwood forest conference, Lexington, KY. Fei, S., Lhotka, J.M., Stringer, J.W. Gottschalk, K.W., and G.W. Miller (eds.). US Forest Service Gen. Tech. Rep. NRS-P-78. 678 p.

Dey, D.C., Douglass, J., McNabb, K., Miller, G., Baldwin, V., and G. Foster. 2008. Artificial regeneration of major oak (Quercus) species in the eastern United States: A review of the Literature. Forest Science 54:77-106.

Dey, D. C., Gardiner, E. S., Schweitzer, C. J., Kabrick, J. M. and D.F. Jacobs. 2012. Underplanting to sustain future stocking of oak (Quercus) in temperate deciduous forests. New Forests.

Dey, D.C. and Parker, W.C. 1997a. Morpholical indicators of stock quality and field performance of red oak (Quercus rubra L.) seedlings underplanted in a central Ontario shelterwood. New Forests. 14:145-156

Dey, D.C. and W.C. Parker. 1997b. Overstory density affects field performance of underplanted red oak (Quercus rubra L.) in Ontario. Northern Journal of Applied Forestry 14:120-125.

Dey, D.C., Spetich, M.A., Weigel, D.R., Johnson, P.S., Graney, D.L. and J.M. Kabrick. 2009. A suggested approach for design of oak (Quercus L.) regeneration research considering regional differenced. New Forests. 37:123-135.

Dey, D. C., Royo, A. A., Brose, P. H., Hutchinson, T. F., Spetich, M. A. and S.H.Stoleson. 2010. An ecologically based approach to oak silviculture: A synthesis of 50 years of oak ecosystem research in North America. Revista Columbia Forestal. 13:201-222.

Donoso, P. J. and R.D. Nyland. 2006. Interference to hardwood regeneration in northeastern North America: The effects of raspberries (Rubus spp.) following clearcutting and shelterwood methods. Northern Journal of Applied Forestry. 23: 288-296. 
Downs, J. D., Williams, R.A. and J.A. Downs. 2011. The effects of shelterwood harvesting on oak regeneration two years after harvest in southern Ohio. P. 262-269 in Proceedings of the 17th central hardwood forest conference, Lexington, KY. Fei, S., Lhotka, J.M., Stringer, J.W. Gottschalk, K.W., and G.W. Miller (eds.). US Forest Service Gen. Tech. Rep. NRS-P-78. 678 p.

Eyre, F.H. (ed). 1980. Forest cover types of the United States and Canada. Society of American Foresters, Bethesda, MD. 148p.

Elliott, K.J., L. Hendrick, R., Major, A.E., Vose, J.M. and W.T. Swank. 1999. Vegetation dynamics after a prescribed fire in the southern Appalachians. Forest Ecology and Management. 114:199-213.

Fedekulegn, D., Hicks, R.R., and Colbert, J.J. 2003. Influence of topographic aspect, precipitation and drought on radial growth of four major tree species in an Appalachian watershed. Forest Ecology and Management 177:409-425.

Fenneman, N.M., and Johnson, D.W. 1946. Physiographic divisions of the conterminous $U$. S. USGS: Washington, D.C.

Gottschalk, K.W. 1994. Shade, leaf growth and crown development of Quercus rubra, Quercus velutina, Prunus serotina and Acer rubrum seedlings. Tree Physiology. 14:735-749.

Guyette, R.P., Dey, D.C., Stambaugh, M.C. and Muzika, R. 2006. Fire scars reveal variability and dynamics of eastern fire regimes. P. 20-39 in Fire in Eastern Oak Forests:

Delivering Science to Land Managers, Proceedings of a Conference. Dickinson, M. B. (ed.) US Forest Service Gen. Tech. Rep. NRS-P-1.

Guyette, R. P., Muzika, R., Kabrick, J. and M. C. Stambaugh. 2004. A perspective on Quercus life history characteristics and forest disturbance. Forest Service Gen. Tech. Rep. SRS73. 183-142.

Hannah, P. R. 1988. The shelterwood method in northeastern forest types: a literature review. Northern Journal of Applied Forestry, 5:70-77.

Hanson, P.J., Dickson, R.E., Iserbrands, J.G., Crow, T.R., and Dixon, R.K. A Morphological Index of Quercus Seedling Ontogeny for Use in Studies of Physiology and Growth. Tree Phsiology. 2, 273-281 (1986).

Hart, J. L.; Buchanan, M. L. 2012. History of fire in eastern oak forests and implications for restoration. P. 34-51 in Proceedings of the 4th fire in eastern oak forests conference. Dey, D. C., Stambaugh, M. C., Clark, S. L., and C.J.Schweitzer (eds.). US Forest Service Gen. Tech. Rep. NRS-P-102. 
Hodges, J.D. and E.S. Gardiner. 1992. Ecology and physiology of oak regeneration. P. 54-65 in Oak regereation: Serious problems, practical recommendations. Loftis, D.L. and C. McGee (eds.). US Forest Service Gen. Tech. Rep. SE-84.

Humbert, L., Gagnon, D., Kneeshaw, D. and C. Messier. 2007. A shade tolerance index for common understory species of northeastern North America. Ecological Indicators. 7:195-207.

Hutchinson, T.F., Sutherland, E.K. and D.A. Yaussy. 2005. Effects of repeated prescribed fires on the structure, composition, and regeneration of mixed-oak forests in Ohio. Forest Ecology and Management. 218:210-228.

Hutchinson, T.F., Long, R.P., Ford, R.D., and E.K. Sutherland. 2008. Fire history and the establishment of oaks and maples in second-growth forests. Canadian Journal of Forest Research. 38:1184-1198.

Heggenstaller, D.J., Zenner, E.K., Brose, P.H. and J.E. Peck. 2012. How much older are Appalachian oaks below-ground than above-ground? Northern Journal of Applied Forestry. 29: 155-157.

Iverson, L.R., Hutchinson, T.F., Prasad, A.M., and M.P. Peters. 2008. Thinning, fire, and oak regeneration across a heterogeneous landscape in the eastern U.S.: 7-year results. Forest Ecology and Management. 255:3035-3050.

Johnson, P.S., Dale, C.D., Davidson, K.R. and J.R. Law. 1986. Planting northern red oak in the Missouri Ozarks: A prescription. Northern Journal of Applied Forestry 3:66-68.

Johnson, P.S., Shifley, S.R. and R. Rogers. 2002. The Ecology and silviculture of oaks. CABI: Wallingford, Oxon: New York.

Kaelke, C.M., Kruger, E.L., and P. B. Reich. 2001. Trade-offs in seedling survival, growth, and physiology among hardwood species of contrasting successional status along a lightavailability gradient. Canadian Journal of Forest Resources. 31: 1602-1616.

Knox, W.M. 1997. Ch. 3: Historical changes in the abundance and distribution of deer in Virginia. P. 27-36 in The science of overabundance: Deer ecology and population management. McShea, W.J., Underwood, H.B., and J.H. Rappole (eds.). Smithsonian Institution Press: Washington, DC.

Kolb, T.E., Steiner, K.C., McCormick, L.H., and T.W.Bowersox, 1990. Growth response of northern red-oak and yellow-poplar seedlings to light, soil moisture and nutrients in relation toecological strategy. Forest Ecology and Management. 38: 65-78.

Larsen, D.R., Johnson, P.S., 1998. Linking the ecology of natural oak regeneration to silviculture. Forest Ecology and Management. 106:1-7. 
Little, R.C., Stroup, W.W., and R.J. Fruend. 2002. SAS ${ }^{\circledR}$ for Linear Models, Fourth Edition. SAS Institute Inc: Cary, NC.

Loftis, David L. 1983. Regenerating southern Appalachian mixed hardwood stands with the shelterwood method. Southern Journal of Applied Forestry 7: 212-217.

Loftis, D.L. 1990. A shelterwood method for regenerating red oak in the Southern Appalachians. Forest Science 36:917-929.

Loftis, D.L. 2004. Upland oak regeneration and management. P. 163-167 in Spetich, M. A. (ed.), Upland oak ecology symposium: history, current conditions, and sustainability. USDA Forest Service, Gen. Tech. Rep. SRS-73.

Lorimer C.G., Chapman, J.W. and W.D. Lambert. 1994. Tall understory vegetation as a factor in the poor development of oak seedlings beneath mature stands. Journal of Ecology 82:227-237.

Lorimer, C.G. 2001. Historical and Ecological Roles of Disturbance in Eastern North American Forests: 9,000 Years of Change. Wildlife Society Bulletin 29:435-439.

Marquis, D.A. and T.J. Grisez. 1978. The effect of deer exclosures on the recovery of vegetation in failed clearcuts on the Allegheny Plateau. Research Note NE-270.

McCabe, W.J. and R.E. McCabe. 1997. Ch. 2: Recounting whitetails past. P. 11-26 in The science of overabundance: Deer ecology and population management, McShea, W.J., Underwood, H.B. and J.H. Rappole (eds.). Smithsonian Institution Press: Washington, DC.

McGee, C.E. \& D.L. Loftis. Planted oaks perform poorly in North Carolina and Tennessee. Northern Journal of Applied Forestry. 3:114-116.

Nowacki, G.J. and M.D. Abrams. 2008. The demise of fire and "mesophication" of Forests in the Eastern United States. BioScience. 58:123-138.

Nuttle, T., Royo, A. A., Adams, M.B., and W. P. Carson. 2013. Historic disturbance regimes promote tree diversity only under low browsing regimes in eastern deciduous forest. Ecological Monographs 83:3-17.

Nyland, R.D. 2007. Silviculture: Concepts and Applications: $2^{\text {nd }}$ edition. Waveland Press, Inc: Long Grove, IL.

Nyland, R.D. 2005. Diameter-Limit Cutting and Silviculture in Northern Hardwoods. In: Kenefic, L. S.; Nyland, R. D. (eds.) Proceedings of the conference on diameter-limit cutting in northeastern forests, Amherst, MA. Gen. Tech. Rep. NE-341. 
Olson, M.G., Clatterbuck, W.K. and S.E. Schlalrbaum. 2006. Survival and growth of underplanted northern red oak on mesic sites in Eastern Tennessee: two-year results. US Forest Service Gen. Tech. Rep. SRS-92. 279-282.

Paquette, A., Bouchard, A. and A. Cogliastro. 2006. Successful under-planting of red oak and black cherry in early-successional deciduous shelterwoods of North America. Annals of Forest Science. 63:823-831.

Patterson, W.A.III. 2009. The paleoecology of fire and oaks in eastern forests. P. 2-19 in Fire in eastern oak forests: delivering science to land managers, Proceedings of a conference. Dickinson, M.B. (ed.). US Forest Service Gen. Tech. Rep. NRS-P-1.

Pyne, S.J. 1997. America's fires: Management on wildlands and forests. Forest History Society: Durham, N.C.

Pyne, S.J. 2001. Fire: A brief history. University of Washington Press: Seattle.

Rebbeck, J. 2012. Fire management and woody invasive plants in oak ecosystems. P.142-155 in Proceedings of the 4th fire in eastern oak forests conference, Springfield, MO. Dey, D. C., Stambaugh, M. C., Clark, S. L., and C.J.Schweitzer (eds.). US Forest Service Gen. Tech. Rep. NRS-P-102.

Rebbeck, J. Scherzer, A. and K. Gottschalk. 2012. Do chestnut, northern red, and white oak germinant seedlings respond similarly to light treatments? II. Gas exchange and chlorophyll responses Canadian Journal of Forest Research. 42:1025-1037.

Reich, P.B., Teskey, R.O., Johnson, P.S. and T.M. Hinckley. 1980. Periodic Root and Shoot Growth in Oak. Forest Science 26:590-598.

Royse, J., Arthur, M. and D. Loftis. 2009. Prescribed fire and oak seedling development in an Appalachian forest. P. 152 in Proceedings of the 3rd fire in eastern oak forests conference, Carbondale, IL. Hutchinson, T.F. (ed.). US Forest Service Gen. Tech. Rep. NRS-P-46.

Sander, I. L. 1971. Height growth of new oak sprouts depends on size of advance reproduction. Journal of Forestry. 69: 809-811.

Sander, I. L., Johnson, P. S. and R . F. Watt.1976. A guide for evaluating the adequacy of oak advance reproduction. USDA Forest Service Gen. Tech. Rep. NC-23.7 p.

Saunders, M.R. and K.J. Puettmann. 1999. Use of Vegetational Characteristics and Browsing Patterns to Predict Deer Damage in Eastern White Pine (Pinus strobus) Plantations. Northern Journal of Applied Forestry. 16:96-102. 
Schlesinger, R. C., Sander, I. L., and K. R. Davidson. 1993. Oak regeneration potential increased by shelterwood treatments. Northern Journal of Applied Foresty. 10: 149-153

Schuler, J.L. and D.J. Robison. 2010. Performance of northern red oak enrichment plantings in naturally regenerating southern Appalachian hardwood stands. New Forests 40:119-130.

Seagle, S.W. and Luh-Yen Liang. 1997. Ch21: Bottomland forest composition and seedling diversity: Simulating succession and browsing by overabundant deer. P. 346-365 in The science of overabundance: Deer ecology and population management, McShea, W.J., Underwood, H.B. and J.H. Rappole (eds.). Smithsonian Institution Press: Washington, DC.

Shafer, E.L., Grisez, T. J., and E. Sowa. 1961. Results of deer exclosure studies in northeastern Pennsylvania. Forest Research Note NE-121. 1-7.

Signell, S.A., Abrams, M.D., Hovis, J.C. and S.W. Henry. 2005. Impact of multiple fires on stand structure and tree regeneration in central Appalachian oak forests. Forest Ecology and Management 218:146-158.

Smith, David. 2006. Why sustain oak forests? P. 62-71 in Fire in eastern oak forests: delivering science to land managers, Proceedings of a conference. Dickinson, M. B. (ed.). US Forest Service Gen. Tech. Rep. NRS-P-1.

Society of American Foresters (SAF). 2008. The dictionary of forestry: Diamter limit cutting. Accessed 15 April 2012. Available online at <http://dictionaryofforestry.org/dict/term/diameter-limit_cutting>.

Spetich, M.A., Dey, D.C., Johnson, P.S. and D.L. Graney. 2002. Competitive capacity of Quercus rubra L. planted in Arkansas’ Boston Mountains. Forest Science 48, 504-517.

Stan, A.B., Rigg, L.S. and L.S. Jones. 2011. Dynamics of a managed oak woodland in northeastern Illinois. Natural Areas Journal 26:187-197.

Thompson, J.R. and R.C. Schultz. 1995. Root system morphology of Quercus rubra L. planting stock and 3-year performance in Iowa. New Forests. 9:225-236.

Tilgham, N.G. 1989. Impacts of white-tailed deer on forest regeneration in northwestern Pennsylvania. The Journal of Wildlife Management. 53(3):524-532.

USDA Forest Service. 2000. Resources Planning Act (RPA) statistical tables, 1997. USDA Forest Service: Washington, DC.

Walters, R. S. and L.R. Auchmoody, L. R. 1993. Factors limiting northern red oak reproduction in Pennsylvania. P.271-280 in Proceedings of the 9th Central Hardwood Forest Conference, West Lafayette, IN. Gillespie, A. R., Parker, G. R., Pope, P. E., and G. Rink (eds.). US Forest Service Gen. Tech. Rep. NC-161. 
Weigel, D.R., Dey, D.C., and J. Kabrick. 2012. The 3Ps of oak regeneration: Planning, patience and persistence. P. 379-380 in Proceedings of the 16th Biennial Southern Silvicultural Research Conference. Butnor, J.R. (ed.) US Forest Service Gen. Tech. Rep. e-GTR-SRS156.

Weigel, D.R. and P. S. Johnson. 2000. Planting red oak under oak/yellow-poplar shelterwoods: A provisional prescription. US Forest Service Gen. Tech. Rep. NC-210.

Widmann, R. H., Cook, G. W., Barnett, C. J., Butler, B. J., Griffith, D. M., Hatfield, M. A., Kurtz, C. M., Morin, R. S., Moser, W. K., Perry, C. H., Piva, R. J., Riemann, R.L. and C. W. Woodall. 2012. West Virginia's Forests 2008. Resource Bulletin. NRS-61. 64 p.

Woodall, C.W, R.S. Morin, J.R. Steinman and C.H. Perry. 2008. Status of oak seedlings and saplings in the northern United States: implications for sustainability of oak forests. P. 435-542 in 16th Central Hardwood Forest Conference, West Lafayette, IN. Jacobs, D. F.; Michler, C. H. (eds.). Proceedings US Forest Service Gen. Tech. Rep. NRS-P-24. 391p.

WV.gov. 2013. "West Virginia Hunters Harvest 131,444 Deer in 2012.” Accessed 2/20/2013. available at <http://www.wv.gov/news/Pages/WestVirginiaHuntersHarvest131,444Deer in2012.aspx\#home>. 


\section{APPENDICES}

APPENDIX A: Site basal area and dominant species

\begin{tabular}{|c|c|c|c|c|}
\hline Province & $\begin{array}{c}\text { Management } \\
\text { Regime }\end{array}$ & Site & $\mathbf{B A}$ & Dominant species (Based off of \%BA) \\
\hline \multirow{10}{*}{ AP } & \multirow{2}{*}{ Control } & DB1 & 30.19 & Q. spp, A. saccharum, F. grandifolia \\
\hline & & DB2 & 37.58 & L. tulipifera, Q. spp., Tilia americana \\
\hline & \multirow{2}{*}{ DLC } & $\mathrm{CL}$ & 16.97 & A. saccharum, $Q$. spp., B. lenta \\
\hline & & PNT & 13.76 & Q. spp, Carya spp., A. saccharum \\
\hline & Repeat Burn & $\mathrm{BB}$ & 22.08 & A. saccharum, Q. spp., Carya spp. \\
\hline & \multirow{3}{*}{ Single Burn } & RHE & 29.90 & Q. spp., A. saccharum \\
\hline & & RHW & 31.80 & Q. spp., L. tulipifera, other hardwoods \\
\hline & & GG & 19.33 & Q. spp., L. tulipifera, A. saccharum \\
\hline & \multirow[t]{2}{*}{ Shelterwood } & PCBR & 12.72 & A. rubrum, $P$. serotina, $Q$. spp., \\
\hline & & PCDF & 10.80 & P. serotina, A. rubrum \\
\hline \multirow{10}{*}{ RV } & \multirow{2}{*}{ Control } & EK & 24.81 & Q. spp., Pinus spp. \\
\hline & & $\mathrm{SR}$ & 28.51 & Q. spp., Pinus spp. \\
\hline & \multirow{2}{*}{ DLC } & GRM & 19.01 & Q. spp., Tsuga canadensis, Pinus spp. \\
\hline & & JN & 25.47 & Q. spp., A. rubrum \\
\hline & \multirow{2}{*}{ Repeat Burn } & $\mathrm{LF}$ & 30.20 & Q. spp., A. saccharum \\
\hline & & NR & 25.24 & Q. spp. \\
\hline & \multirow{2}{*}{ Single Burn } & $\mathrm{CR}$ & 25.03 & Q. spp. \\
\hline & & HS & 27.70 & Q. spp., Pinus spp. \\
\hline & \multirow{2}{*}{ Shelterwood } & SR2 & 1.59 & Q. spp. \\
\hline & & SR710 & 3.24 & Q. spp. \\
\hline
\end{tabular}


APPENDIX B: Site Sapling densities (stems/ha) by shade tolerance class

\begin{tabular}{cclrrrrr}
\hline Province & $\begin{array}{c}\text { Management } \\
\text { Regime }\end{array}$ & Site & Intolerant & Intermediate & Tolerant & Oaks & Total \\
\hline \multirow{4}{*}{ Control } & DB1 & 0.00 & 83.33 & 3250.00 & 0.00 & 3333.33 \\
& & DB2 & 166.67 & 583.33 & 2916.67 & 500.00 & 3666.67 \\
& DLC & CL & 0.00 & 0.00 & 2000.00 & 0.00 & 2000.00 \\
& PNT & 0.00 & 250.00 & 1250.00 & 0.00 & 1500.00 \\
AP & Repeat Burn & BB & 0.00 & 500.00 & 1750.00 & 0.00 & 2250.00 \\
& Single Burn & RHE & 0.00 & 0.00 & 500.00 & 0.00 & 500.00 \\
& & RHW & 0.00 & 0.00 & 416.67 & 0.00 & 416.67 \\
& GG & 333.33 & 1000.00 & 3666.67 & 83.33 & 5000.00 \\
& Shelterwood & PCBR & 833.33 & 0.00 & 416.67 & 0.00 & 1250.00 \\
& & PCDF & 9833.33 & 83.33 & 583.33 & 0.00 & 10500.00 \\
\hline \multirow{4}{*}{ Control } & EK & 0.00 & 83.33 & 83.33 & 83.33 & 166.67 \\
& & SR & 0.00 & 0.00 & 100.00 & 0.00 & 100.00 \\
& DLC & GRM & 0.00 & 166.67 & 83.33 & 0.00 & 250.00 \\
& JN & 0.00 & 0.00 & 0.00 & 0.00 & 0.00 \\
& Repeat Burn & LF & 83.33 & 0.00 & 500.00 & 0.00 & 583.33 \\
& & NR & 0.00 & 0.00 & 142.86 & 0.00 & 142.86 \\
& Single Burn & CR & 0.00 & 83.33 & 250.00 & 83.33 & 333.33 \\
& HS & 0.00 & 83.33 & 0.00 & 0.00 & 83.33 \\
& & SR2 & 100.00 & 0.00 & 250.00 & 0.00 & 350.00 \\
& Shelterwood & SR710 & 200.00 & 0.00 & 150.00 & 0.00 & 350.00 \\
\hline
\end{tabular}

\begin{tabular}{c|c|cc}
\hline Intolerant & Intermediate & \multicolumn{2}{|c}{ Tolerant } \\
\hline Betula sp. & Asimina triloba & Acer sp. & Cornus florida \\
Fraxinus sp. & Castanea dentata & Aeschulus flava & Fagus grandifolia \\
Liriodendron tulipifera & Magnolia sp. & Amelanchier arborea & Illex montana \\
Populus sp. & Pinus stobus & Aralia spinosa & Nyssa sylvatica \\
Prunus sp. & Quercus sp. & Carpinus caroliniana & Ostrya virginiana \\
Sassafras albidum & Carya sp. & Cercis canadensis & Oxydendrum arboreum \\
Robinia psuedoacacia & & Tsuga canadensis & Tilia americana \\
& & Ulmus rubra & \\
\hline
\end{tabular}


APPENDIX C: Site seedling densities (stems/ha) by shade tolerance class

\begin{tabular}{|c|c|c|c|c|c|c|c|}
\hline Province & $\begin{array}{c}\text { Management } \\
\text { Regime }\end{array}$ & Site & Intolerant & Intermediate & Tolerant & Oaks & Total \\
\hline \multirow{10}{*}{$\mathrm{AP}$} & \multirow{2}{*}{ Control } & DB1 & 10625 & 56875 & 26375 & 56125 & 93875 \\
\hline & & DB2 & 31500 & 18125 & 30250 & 16875 & 79875 \\
\hline & \multirow{2}{*}{ Single Burn } & RHE & 20125 & 3875 & 54875 & 1625 & 78875 \\
\hline & & RHW & 12500 & 2125 & 27125 & 875 & 41750 \\
\hline & Repeat Burn & BB & 6625 & 3625 & 27250 & 2250 & 37500 \\
\hline & \multirow{3}{*}{ DLC } & CL & 134625 & 625 & 71625 & 250 & 206875 \\
\hline & & PNT & 20125 & 8000 & 15625 & 6375 & 43750 \\
\hline & & GG & 27000 & 6375 & 38000 & 4625 & 71375 \\
\hline & \multirow[t]{2}{*}{ Shelterwood } & PCBR & 67125 & 1500 & 40750 & 375 & 109375 \\
\hline & & PCDF & 287125 & 10125 & 44500 & 875 & 341750 \\
\hline \multirow{10}{*}{$\mathrm{RV}$} & \multirow{2}{*}{ Control } & EK & 1250 & 7125 & 41875 & 3000 & 50250 \\
\hline & & SR & 2875 & 2750 & 15625 & 2000 & 21250 \\
\hline & \multirow{2}{*}{ Single Burn } & $\mathrm{CR}$ & 31500 & 6000 & 10750 & 5125 & 48250 \\
\hline & & HS & 2375 & 9500 & 14375 & 7125 & 26250 \\
\hline & \multirow{2}{*}{ Repeat Burn } & $\mathrm{LF}$ & 8125 & 750 & 77500 & 250 & 86375 \\
\hline & & NR & 1000 & 1375 & 33625 & 1250 & 36000 \\
\hline & \multirow{2}{*}{ DLC } & GRM & 7250 & 19375 & 31000 & 375 & 57625 \\
\hline & & $\mathrm{JN}$ & 18000 & 1000 & 242500 & 750 & 261500 \\
\hline & \multirow{2}{*}{ Shelterwood } & SR2 & 11875 & 15000 & 21125 & 14875 & 48000 \\
\hline & & SR710 & 49079 & 1974 & 25789 & 1184 & 76842 \\
\hline
\end{tabular}


APPENDIX D: Percent cover of woody and herbaceous understory vegetation by site

\begin{tabular}{|c|c|c|c|c|c|c|c|}
\hline & \multirow{2}{*}{\multicolumn{5}{|c|}{ \% Cover }} \\
\hline & & & & & & & \\
\hline Province & $\begin{array}{c}\text { Management } \\
\text { Regime }\end{array}$ & Site & Fern & Blackberry & Shrub/Vine & $\begin{array}{c}\text { Other } \\
\text { Herbaceous }\end{array}$ & Total \\
\hline \multirow[t]{10}{*}{ AP } & Control & DB1 & 2.65 & 0.89 & 1.02 & 0.89 & 5.45 \\
\hline & & DB2 & 1.14 & 0.08 & 1.02 & 3.68 & 5.92 \\
\hline & DLC & $\mathrm{CL}$ & 1.59 & 1.16 & 1.17 & 5.40 & 9.31 \\
\hline & & PNT & 1.65 & 0.62 & 4.11 & 15.73 & 22.11 \\
\hline & Repeat Burn & $\mathrm{BB}$ & 0.51 & 0.06 & 2.27 & 4.41 & 7.24 \\
\hline & Single Burn & RHE & 0.92 & 0.09 & 3.14 & 3.03 & 7.19 \\
\hline & & RHW & 1.07 & 0.10 & 0.58 & 3.74 & 5.49 \\
\hline & Shelterwood & GG & 0.45 & 0.83 & 4.60 & 7.16 & 13.03 \\
\hline & & PCBR & 1.80 & 10.97 & 11.47 & -9.14 & 15.10 \\
\hline & & PCDF & 2.83 & 53.39 & 53.99 & -52.58 & 57.63 \\
\hline \multirow[t]{10}{*}{$\mathrm{RV}$} & Control & EK & 0.00 & 0.00 & 6.03 & 1.02 & 7.05 \\
\hline & & SR & 0.42 & 0.02 & 1.77 & 0.07 & 2.27 \\
\hline & DLC & GRM & 12.19 & 0.01 & 0.10 & 0.63 & 12.94 \\
\hline & & $\mathrm{JN}$ & 0.10 & 0.00 & 0.26 & 0.16 & 0.52 \\
\hline & Repeat Burn & $\mathrm{LF}$ & 2.92 & 0.00 & 9.80 & 2.48 & 15.20 \\
\hline & & NR & 1.41 & 0.04 & 6.00 & 6.34 & 13.78 \\
\hline & Single Burn & $\mathrm{CR}$ & 0.20 & 0.12 & 1.02 & 1.71 & 3.05 \\
\hline & & HS & 0.00 & 0.00 & 9.64 & 0.35 & 9.99 \\
\hline & Shelterwood & SR2 & 0.80 & 0.03 & 6.26 & 9.46 & 16.55 \\
\hline & & SR710 & 0.11 & 1.03 & 1.23 & 14.57 & 16.95 \\
\hline
\end{tabular}


APPENDIX E: Global Site Factor by site

\begin{tabular}{|c|c|c|c|}
\hline Province & $\begin{array}{c}\text { Management } \\
\text { Regime }\end{array}$ & Site & GSF (SE) \\
\hline \multirow{10}{*}{ AP } & \multirow{2}{*}{ Control } & DB1 & $2.8(0.4)$ \\
\hline & & DB2 & $2.9(0.6)$ \\
\hline & \multirow{2}{*}{ Single Burn } & RHE & $7.5(0.7)$ \\
\hline & & RHW & $5.5(0.6)$ \\
\hline & Repeat Burn & $\mathrm{BB}$ & $4.4(0.3)$ \\
\hline & \multirow{3}{*}{ DLC } & $\mathrm{CL}$ & $16.2(2.5)$ \\
\hline & & PNT & $5.8(0.7)$ \\
\hline & & GG & $10(2.3)$ \\
\hline & \multirow[t]{2}{*}{ Shelterwood } & PCBR & $26.8(3.2)$ \\
\hline & & PCDF & $22(4.1)$ \\
\hline \multirow{10}{*}{$\mathrm{RV}$} & \multirow{2}{*}{ Control } & EK & $9(1.2)$ \\
\hline & & SR & $7.9(1.5)$ \\
\hline & \multirow{2}{*}{ Single Burn } & $\mathrm{CR}$ & $13(1.7)$ \\
\hline & & HS & $11.1(0.8)$ \\
\hline & \multirow{2}{*}{ Repeat Burn } & $\mathrm{LF}$ & $11.3(0.9)$ \\
\hline & & NR & $16.4(1.0)$ \\
\hline & \multirow{2}{*}{ DLC } & GRM & $35(3.4)$ \\
\hline & & $\mathrm{JN}$ & $7.8(1.0)$ \\
\hline & \multirow{2}{*}{ Shelterwood } & SR2 & $69(2.6)$ \\
\hline & & SR710 & $61.3(3.6)$ \\
\hline
\end{tabular}


